\title{
Transmembrane Domain I Contributes to the Permeation Pathway for Serotonin and Ions in the Serotonin Transporter
}

\author{
Eric L. Barker, Kimberly R. Moore, Fariborz Rakhshan, and Randy D. Blakely \\ Department of Pharmacology and Center for Molecular Neuroscience, Vanderbilt University School of Medicine, \\ Nashville, Tennessee 37232-6600
}

Mutation of a conserved Asp (D98) in the rat serotonin (5HT) transporter (rSERT) to Glu (D98E) led to decreased 5HT transport capacity, diminished coupling to extracellular $\mathrm{Na}^{+}$and $\mathrm{Cl}^{-}$, and a selective loss of antagonist potencies (cocaine, imipramine, and citalopram but not paroxetine or mazindol) with no change in $5 \mathrm{HT} K_{\mathrm{m}}$ value. D98E, which extends the acidic side chain by one carbon, affected the rank-order potency of substrate analogs for inhibition of $5 \mathrm{HT}$ transport, selectively increasing the potency of two analogs with shorter alkylamine side chains, gramine, and dihydroxybenzylamine. D98E also increased the efficacy of gramine relative to $5 \mathrm{HT}$ for inducing substrate-activated currents in Xenopus laevis oo- cytes, but these currents were noticeably dependent on extracellular medium acidification. $I-V$ profiles for substrateindependent and -dependent currents indicated that the mutation selectively impacts ion permeation coupled to $5 \mathrm{HT}$ occupancy. The ability of the D98E mutant to modulate selective aspects of substrate recognition, to perturb ion dependence as well as modify substrate-induced currents, suggests that transmembrane domain I plays a critical role in defining the permeation pathway of biogenic amine transporters.

Key words: serotonin; monoamine; transporter; biological transport; carrier proteins; molecular structure; permeation channel; selectivity filter
The $\mathrm{Na}^{+}$- and $\mathrm{Cl}^{-}$-dependent neurotransmitter transporters play a major role in the dynamic regulation of extracellular neurotransmitter concentrations. Not including species variants, this family of transporters is composed of more than 15 distinct members, including carriers for amino acid neurotransmitters as well as the monoamines serotonin (5HT), norepinephrine (NE), epinephrine, and dopamine (DA) (Nelson, 1998). The 5HT transporter (SERT, 5HTT) is of particular clinical interest because it is a target for many antidepressants such as the tricyclic imipramine and the 5HT-selective reuptake inhibitors (SSRIs), including fluoxetine and paroxetine (Barker and Blakely, 1995; Tatsumi et al., 1997) as well as abused psychostimulants, including cocaine and the amphetamines (Rudnick and Wall, 1992; White, 1998). Initial structural inferences suggest that the biogenic amine transporters exhibit cytoplasmic NH2 and $\mathrm{COOH}$ tails, 12 putative transmembrane domains (TMDs), and a large extracellular loop between TMDs III and IV containing multiple sites for N-glycosylation (Nelson, 1998). Although there has been some controversy regarding this model (Bennett and Kanner, 1997; Clark, 1997), recent studies using the substituted cysteine accessibility method (SCAM) (Akabas et al., 1992; Stauffer and Karlin, 1994) have examined and supported the 12 TMD topology (Chen

Received Jan. 29, 1999; revised March 23, 1999; accepted March 26, 1999.

This work was supported by National Institutes of Health Grants R01-DA07390 (R.D.B.) and F32-DA05679 (E.L.B.) and a National Alliance for Research on Schizophrenia and Depression Established Investigator Award (R.D.B.). We acknowledge the effort of Robert Gereau and Susan Taylor-Rouse (Emory University) for assistance in the generation of the SERT and NET mutants. We also thank Louis DeFelice, Aurelio Galli, Christina Petersen, and Ian Scott Ramsey for helpful discussions and critical reviews of this manuscript.

Correspondence should be addressed to Dr. Randy D. Blakely, MRBII Room 419, Center for Molecular Neuroscience, Vanderbilt School of Medicine, Nashville, TN 37232-6600.

Dr. Barker's and Dr. Rakhshan's present address: Department of Medicinal Chemistry and Molecular Pharmacology, Purdue University School of Pharmacy, W. Lafayette, IN 47907.

Copyright (C) 1999 Society for Neuroscience $\quad 0270-6474 / 99 / 194705-13 \$ 05.00 / 0$ et al., 1998). Despite a knowledge of the primary structure of SERTs and related transporters, little data are available that define how these domains interact with substrates and antagonists.

5HT transport studies of mammalian SERTs have provided mechanistic data for the kinetics governing the translocation of organic and ionic substrates through the membrane. 5HT influx is a co-transport process coupled to the inward movement of $\mathrm{Na}^{+}$ and $\mathrm{Cl}^{-}$with a predicted stoichiometry of $15 \mathrm{HT} / 1 \mathrm{Na}^{+} / 1 \mathrm{Cl}^{-}$ for influx along with the countertransport of $1 \mathrm{~K}^{+}$, thus predicting a transport cycle that is electrically neutral (Rudnick et al., 1983; Gu et al., 1994; Rudnick, 1998a). However, additional ion conducting states have been associated with SERTs (Mager et al., 1994; Lester et al., 1996) as well as homologous NE (Galli et al., 1995, 1996) and DA transporters (Sonders et al., 1997). For SERTs, these conducting states include (1) a constitutive leak pathway and (2) a substrate-activated current. In Xenopus laevis oocytes expressing rat SERT (rSERT), both the SERT leak and substrate-gated currents are potentiated by medium acidification, suggesting that the transporter is also highly permeable to protons (Cao et al., 1997, 1998). Whether these ion-conducting states use a common permeation pathway and whether this pathway is shared with the pathway along which 5HT translocates is currently unknown.

The availability of cDNAs encoding SERTs provides the molecular tools necessary for a structural dissection of the transporter to identify residues or domains critical for substrate recognition and translocation, ion coupling, and antagonist blockade. In the present studies, we identified a residue in TMD I with a binary option (Asp or Gly) among the $\mathrm{Na}^{+}$- and $\mathrm{Cl}^{-}$-dependent transporters and established that reversal of this residue in either human norepinephrine transporter (NET) (D75G) or rat SERT (D98G), or several other substitutions, caused a disruption of amine transport activity. However, the rSERT mutant D98E 
retained significant $5 \mathrm{HT}$ transport activity, allowing us to explore the consequences of this more conservative substitution on substrate and antagonist recognition, ion dependence, and SERTmediated ion flow. Our findings link determinants of 5HT, ion recognition, and nonstoichiometric ion flow, suggesting that TMD I is one of several domains that may line a common permeation pathway for permeant species transiting the membrane through biogenic amine transporters.

\section{MATERIALS AND METHODS}

Site-directed mutagenesis. Point mutations were introduced into the wildtype rSERT and hNET cDNAs by oligonucleotide-directed mutagenesis as described previously (Kunkel et al., 1987). A single-stranded uracilcontaining DNA template was generated in Escherichia coli CJ236 (dut-, ung-) (Invitrogen) using R408 helper phage. Using oligonucleotides encoding the mutations, the following mutations were introduced: rSERT D98A, D98E, D98G, D98N, D98T, and hNET D75A, D75E, $\mathrm{D} 75 \mathrm{G}$, and $\mathrm{D} 75 \mathrm{~N}$. Identity of the mutant cDNAs was confirmed by dideoxynucleotide sequencing using a Sequenase-II kit (United States Biochemicals) (Sanger et al., 1977). To verify the absence of additional mutations in the parental cDNAs, rescue constructs of all mutations were constructed. For the SERT mutant rescues, the XhoI/RsrII fragment containing the various D98 mutations was removed from the mutantcontaining cDNAs, and the corresponding fragment from the wild-type rSERT cDNA was ligated into D98 mutant cDNAs. For the hNET mutant rescues, the $S c a$ I fragment containing the various D75 mutations was removed from the mutant-containing cDNA, and the corresponding fragment from the wild-type hNET was ligated into the D75 mutant constructs. The rescue constructs were tested for recovery of transport activity in either $\left[{ }^{3} \mathrm{H}\right] 5 \mathrm{HT}$ or $\left[{ }^{3} \mathrm{H}\right] \mathrm{NE}$ uptake experiments. In all cases, the rescue constructs demonstrated wild-type rSERT or hNET transport activity (data not shown), confirming that the disruption of transport activity observed for the rSERT D98 and hNET D75 mutants resulted from the single mutation.

Transient expression of SERTs in mammalian cells. To directly assess transport activity of rSERT (Blakely et al., 1991a) and the rSERT D98 mutants, as well as hNET (Pacholczyk et al., 1991) and hNET mutants, transient expression of the transporters was achieved using the recombinant vaccinia virus T7 expression system in HeLa cells (Fuerst et al., 1986; Blakely et al., 1991b). The parental cDNAs, rSERT and hNET, were previously cloned into the plasmids pBluescript II KS - and pBluescript II SK+, respectively. In each case, sense RNA is transcribed by the plasmid-encoded T7 RNA polymerase promoter. HeLa cells were cultured in DMEM supplemented with $10 \%$ fetal bovine serum, $2 \mathrm{~mm}$ L-glutamine, and $1 \%$ penicillin/streptomycin at $37^{\circ} \mathrm{C}$ in a humidified $5 \%$ $\mathrm{CO}_{2}$ incubator. Cells plated in 24-well culture plates $(100,000$ cells per well) were infected with recombinant VVT7-3 vaccinia virus encoding T7 RNA polymerase at 10 plaque-forming units per cell as described (Fuerst et al., 1986; Blakely et al., 1991b). Virus infection of the cells proceeded for $30 \mathrm{~min}$ in serum-free Opti-MEM I containing $55 \mu \mathrm{M}$ 2-mercaptoethanol at $37^{\circ} \mathrm{C}$. After virus infection, SERT or NET cDNA constructs were transfected into virus-infected HeLa cells using liposome-mediated transfection (Lipofectin reagent) at $100 \mathrm{ng}$ DNA per well at a ratio of $1 \mu \mathrm{g}$ of DNA/3 $\mu \mathrm{g}$ of Lipofectin (mixed in Opti-MEM $\mathrm{I} / \beta$-mercaptoethanol).

For expression in COS-7 cells, rSERT and rSERT D98E were subcloned into the $X h o \mathrm{I} / X b a \mathrm{I}$ site of the mammalian expression vector pcDNA3 (Invitrogen). This construct would place SERT expression under control of the cytomegalovirus promoter suitable for expression in COS-7 cells. Parental COS-7 cells were cultured in DMEM supplemented with $10 \%$ fetal bovine serum, $2 \mathrm{~mm}$ glutamine, and $1 \%$ penicillin/ streptomycin at $37^{\circ} \mathrm{C}$ in a humidified $5 \% \mathrm{CO}_{2}$ environment. For uptake experiments, 100,000 cells per well were plated in 24-well culture plates (Falcon) and transfected with rSERT or D98E cDNA using $100 \mathrm{ng} / \mathrm{well}$ and a 5:1 ratio of Lipofectin reagent/DNA. Medium containing DNA and Lipofectin was removed 16-18 hr after transfection and replaced with complete DMEM culture medium. Cells were used in uptake assays $48 \mathrm{hr}$ later. For cell-surface biotinylation experiments, cells (200,000 cells per well) in six-well culture plates were transfected with rSERT or D98E cDNA using $2 \mu \mathrm{g}$ DNA/well and a 5:1 ratio of Lipofectin/DNA. Medium containing DNA and Lipofectin was removed $16-18 \mathrm{hr}$ after transfection and replaced with complete DMEM culture medium. Cells were used in biotinylation experiments (see below) $48 \mathrm{hr}$ later. $\left[{ }^{3} \mathrm{H}\right] 5 \mathrm{HT}$ and $\left[{ }^{3} \mathrm{H}\right] \mathrm{NE}$ transport assays. Transfected HeLa or COS-7 cells were washed with a Krebs'-Ringer's-HEPES (KRH) buffer (120 mM $\mathrm{NaCl}, 4.7 \mathrm{~mm} \mathrm{KCl}, 2.2 \mathrm{~mm} \mathrm{CaCl}_{2}, 10 \mathrm{~mm} \mathrm{HEPES}, 1.2 \mathrm{~mm} \mathrm{KH}_{2} \mathrm{PO}_{4}, 1.2$ $\mathrm{mM} \mathrm{MgSO}_{4}, \mathrm{pH} 7.4$ ). Cells were preincubated for $10 \mathrm{~min}$ at $37^{\circ} \mathrm{C}$ in $\mathrm{KRH}$ containing $1.8 \mathrm{gm} / \mathrm{l} \mathrm{D}$-glucose, and then transport assays with $10 \mathrm{~nm}$ $\left[{ }^{3} \mathrm{H}\right]-5 \mathrm{HT}(\sim 100 \mathrm{Ci} / \mathrm{mmol}$; Amersham $), 100 \mu \mathrm{M}$ pargyline, and $100 \mu \mathrm{M}$ L-ascorbic acid or $40 \mathrm{nM}\left[{ }^{3} \mathrm{H}\right] \mathrm{NE}$ ( $\sim 50 \mathrm{Ci} / \mathrm{mmol}$; Amersham), $100 \mu \mathrm{M}$ pargyline, $100 \mu \mathrm{M}$ L-ascorbic acid, and $100 \mu \mathrm{M}$ U-0521 were performed for $10 \mathrm{~min}$ at $37^{\circ} \mathrm{C}$. Inhibitors were added in the preincubation step. Saturation kinetics were determined using increasing concentrations of $\left[{ }^{3} \mathrm{H}\right] 5 \mathrm{HT}$ with the specific activity diluted to $\sim 0.1 \mathrm{Ci} / \mathrm{mmol}$ with unlabeled $5 \mathrm{HT}$. Uptake was terminated by three washes with ice-cold KRH buffer. The level of accumulated $\left[{ }^{3} \mathrm{H}\right] 5 \mathrm{HT}$ or $\left[{ }^{3} \mathrm{H}\right] \mathrm{NE}$ was determined either by solubilizing cells in $1 \%$ SDS and analysis by liquid scintillation spectrometry or by solubilizing directly in scintillant (Optiphase SuperMix) with direct counting of culture plate in a Wallac MicroBeta plate reader. The $\mathrm{Na}^{+}$dependence of $\left[{ }^{3} \mathrm{H}\right] 5 \mathrm{HT}$ uptake was assessed in KRH buffer using isotonic replacement of $\mathrm{NaCl}$ with $\mathrm{LiCl}$ or $N$-methyl-Dglucamine (NMDG) with equivalent results, whereas the $\mathrm{Cl}^{-}$dependence was determined in $\mathrm{KRH}$ buffer with $\mathrm{Cl}^{-}$salts replaced by sodium gluconate, potassium gluconate, and calcium nitrate at molarities equivalent to those in regular KRH buffer. Nonspecific $\left[{ }^{3} \mathrm{H}\right] 5 \mathrm{HT}$ transport was assessed by parallel transfections with the host plasmid pBluescript SK II(-) alone and subtracted from the total counts. Substrate $K_{\mathrm{m}}$ and antagonist $K_{\mathrm{i}}$ values were derived by nonlinear least-square fits (Kaleidagraph, Synergy Software) using either the Hill equation for a rectangular hyperbola or the four-parameter logistic equation with necessary adjustments of $\mathrm{IC}_{50}$ values for substrate concentration to determine apparent $K_{\mathrm{i}}$ values (Cheng and Prusoff, 1973). Experiments were performed in duplicate or triplicate and repeated in two to three separate assays. Means were compared using two-sided Student's $t$ tests (GraphPad InStat for MacIntosh, v. 2.03) or one-way ANOVA (GraphPad PRISM for Mac, v. 2.0).

$\left[{ }^{125}\right.$ I]RTI-55 binding. Radioligand binding experiments using $\left[{ }^{125}\right.$ I]RTI-55 (NEN Life Science Products; $~ 2200 \mathrm{Ci} / \mathrm{mmol}$ ) were performed on wild-type and mutant rSERTs to assess whether mutationinduced alterations in transport correlated with changes in ligand binding. To prepare crude membranes, HeLa cells were transfected with SERT cDNAs as described for transport assays, except that cells were plated on $150 \mathrm{~mm}$ culture dishes and used 12-16 hr after transfection to maximize SERT expression. Cells were washed with PBS, incubated in ice-cold hypotonic buffer (Tris-HCl $50 \mathrm{~mm}, \mathrm{pH}$ 7.4, NaCl $100 \mathrm{~mm}$ ), detached from the plates using a cell scraper, and pelleted at $1600 \times g$. The resulting pellet was resuspended in ice-cold Tris/ $\mathrm{NaCl}$ buffer and centrifuged for $20 \mathrm{~min}$ at $20,000 \times \mathrm{g}$. The resulting pellet was resuspended with a Brinkmann polytron ( $5 \mathrm{sec}, 25,000 \mathrm{rpm})$ and centrifuged for an additional $20 \mathrm{~min}$ at $20,000 \times g$. The pellet was suspended in Tris/ NaCl buffer and homogenized with the polytron (10 sec, 20,000 $\mathrm{rpm})$. Samples of membrane suspensions were frozen at $-80^{\circ} \mathrm{C}$ before use. Typically, assays were performed using $1 \mu \mathrm{g}$ (rSERT) and $10 \mu \mathrm{g}$ (D98E) of membrane protein as determined by the Bradford protein assay (Bio-Rad) using bovine serum albumin as the standard. Saturation binding was determined in duplicate using $0.1-20 \mathrm{nM}\left[{ }^{125} \mathrm{I}\right] \mathrm{RTI}-55$ with 1 $\mu \mathrm{M}$ paroxetine used to define nonspecific binding $\left(K_{\mathrm{d}}\right.$ and $B_{\max }$ values: wild-type rSERT $0.37 \pm 0.02 \mathrm{nM}$ and $5.6 \pm 0.45 \times 10^{-12} \mathrm{~mol} / \mathrm{mg}$ protein; D98E $3.7 \pm 0.6 \mathrm{nM}$ and $5.4 \pm 0.35 \times 10^{-12} \mathrm{~mol} / \mathrm{mg}$ protein). In competition binding experiments, cells were incubated with increasing concentrations of antagonist before the addition of either $0.1 \mathrm{~nm}$ (wildtype rSERT) or $1.0 \mathrm{nM}$ (D98E) [ $\left.{ }^{125} \mathrm{I}\right] \mathrm{RTI}$-55. Assay tubes were incubated for $1 \mathrm{hr}$ at $22^{\circ} \mathrm{C}$ and filtered using a Brandel harvester through Schleicher and Schuell \#32 glass fiber filters soaked in $0.5 \%$ polyethylenimine. Bound radioactivity was measured by gamma emission spectrometry. $K_{\mathrm{i}}$ values were derived by nonlinear least-square fits (Kaleidagraph, Synergy Software) using a four-parameter logistic equation with necessary adjustments of $\mathrm{IC}_{50}$ values for radioligand concentration to determine apparent $K_{\mathrm{i}}$ values (Cheng and Prusoff, 1973).

Cell-surface biotinylation of SERT and NET proteins. To determine cell-surface expression levels of the wild-type rSERT, rSERT D98E, rSERT D98G, wild-type hNET, hNET D75E, and hNET D75G, cellsurface biotinylation studies using polyclonal antibodies to either rSERT or hNET for protein detection were undertaken as described previously (Melikian et al., 1996; Qian et al., 1997). Because of technical limitations regarding the use of the T7-vaccinia virus expression system for quantitative cell-surface biotinylation (Melikian et al., 1996), all cDNAs were 
subcloned into the mammalian expression vector pcDNA3 (Invitrogen) for transient expression in COS-7 cells. Forty-eight hours after transfection, cells were washed with cold PBS/Ca-Mg (138 mM NaCl, $2.7 \mathrm{~mm}$ $\mathrm{KCl}, 1.5 \mathrm{mM} \mathrm{KH}_{2} \mathrm{PO}_{4}, 9.6 \mathrm{mM} \mathrm{Na}_{2} \mathrm{HPO}_{4}, 1 \mathrm{~mm} \mathrm{MgCl}$, $0.1 \mathrm{~mm} \mathrm{CaCl}$, $\mathrm{pH}$ 7.3) and then treated with freshly prepared Sulfo-NHS-Biotin (sulfosuccinimidobiotin; Pierce) $(1.5 \mathrm{mg} / \mathrm{ml}$ in $\mathrm{PBS} / \mathrm{Ca}-\mathrm{Mg})$ at $4^{\circ} \mathrm{C}$ for 30 min. Biotinylating reagents were removed by washing with $100 \mathrm{~mm}$ glycine in $\mathrm{PBS} / \mathrm{Ca}-\mathrm{Mg}$, the reaction was further quenched by incubation with $100 \mathrm{~mm}$ glycine for $20 \mathrm{~min}$, and then cells were washed with PBS/Ca-Mg before lysis with RIPA buffer (10 mm Tris-Base, $\mathrm{pH}$ 7.4, 150 mm NaCl, 1 mm EDTA, $0.1 \%$ SDS, $1 \%$ Triton X-100, $1 \%$ sodium deoxycholate) supplemented with protease inhibitors $(1 \mu \mathrm{g} / \mathrm{ml}$ leupeptin, $1 \mu \mathrm{M}$ pepstatin, $1 \mathrm{mg} / \mathrm{ml}$ soybean trypsin inhibitors, $1 \mathrm{~mm}$ iodoacetamide, and $250 \mathrm{~mm}$ PMSF) for $30 \mathrm{~min}$ at $4^{\circ} \mathrm{C}$ with constant shaking. Lysates were centrifuged at $20,000 \times \mathrm{g}$ for $30 \mathrm{~min}$ at $4^{\circ} \mathrm{C}$, and supernatants were incubated with monomeric avidin beads $(175 \mu \mathrm{l}$ bead volume/1250 $\mu \mathrm{l}$ supernatant) for $1 \mathrm{hr}$ at room temperature. Beads were washed four times with RIPA, and adsorbed proteins were eluted with $50 \mu \mathrm{l}$ of $2 \times$ Laemmli

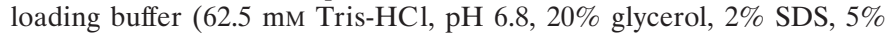
$\beta$-mercaptoethanol, and $5 \%$ bromophenol blue) for $30 \mathrm{~min}$ at room temperature. A fraction of total cell lysate $(20$ of $800 \mu \mathrm{l})$, lysates after incubation with avidin beads (intracellular proteins) $(20$ of $800 \mu \mathrm{l})$, the final wash $(40$ of $800 \mu \mathrm{l})$, and the entire bead eluate $(50 \mu \mathrm{l})$ were separated by SDS-PAGE (10\%), transferred for $16 \mathrm{hr}$ at $150 \mathrm{~mA}$ onto polyvinylidene difluoride membrane, blocked with $5 \%$ nonfat dry milk in PBS $/ 0.1 \%$ Tween- 80 , and immunoblotted with anti-SERT CT-2 (1:5000) (Qian et al., 1995) or anti-NET (1:5000) (Melikian et al., 1994) antibodies using 1:5000 goat anti-rabbit HRP-conjugated secondary antibody. Subsequently, blots were stripped (62.5 mm Tris-HCl, $\mathrm{pH} 6.8,2 \%$ SDS, and $100 \mathrm{~mm} \beta$-mercaptoethanol) for $30 \mathrm{~min}$ at $50^{\circ} \mathrm{C}$, washed with PBS/ Tween-80 twice for $10 \mathrm{~min}$, reblocked with $5 \%$ dry milk for $1 \mathrm{hr}$, and probed with anti-calnexin antibody (StressGen) (1:3000) followed by goat anti-rabbit HRP-conjugated secondary antibody (1:5000). Immunoreactive bands were visualized by ECL chemiluminescent detection (Amersham) on Hyperfilm ECL (Amersham), and scanned bands were quantitated using ImageQuant (Molecular Dynamics). Multiple exposures were used to insure quantitation within the linear range of the film. Values of SERT or NET surface proteins were normalized by levels of calnexin immunoreactivity in total cell extracts and biotinylated (cellsurface) fractions compared with the total fractions to control for different expression levels of each clone.

Two-electrode voltage clamp of SERT-expressing Xenopus oocytes. The plasmids (pBluescript SK II $(-)$ ) containing the cDNAs for either wildtype rSERT (Blakely et al., 1991a) or the D98E mutant were linearized with $X b a \mathrm{I}$, and cRNA was transcribed using the mMessage mMachine T7 In Vitro Transcription Kit (Ambion). Stage V and VI defolliculated oocytes were subsequently injected with 50-100 ng of either wild-type rSERT or D98E cRNA and maintained at $18^{\circ} \mathrm{C}$ in $\mathrm{Ca}^{2+}$-Ringer's solution ( $96 \mathrm{~mm} \mathrm{NaCl}, 2 \mathrm{~mm} \mathrm{KCl}, 5 \mathrm{~mm} \mathrm{MgCl}_{2}, 5 \mathrm{~mm}$ HEPES, and $0.6 \mathrm{mM} \mathrm{CaCl}_{2}, \mathrm{pH}$ 7.6) supplemented with $1 \%$ penicillin/streptomycin (Life Technologies/BRL) and 5\% horse serum (Life Technologies/ BRL). Isotonic replacement of $\mathrm{Na}^{+}$with $\mathrm{NMDG}$ was used in the $\mathrm{Ca}^{2+}$-Ringer's solution for experiments performed in the absence of $\mathrm{Na}^{+}$. Oocytes were used 6-8 d after cRNA injection. Resting membrane potentials for oocytes used in recording experiments ranged from -39 to $-52 \mathrm{mV}$.

Two-electrode voltage-clamp was performed on SERT-expressing oocytes using an AxoClamp 2A (Axon Instruments). Voltage-clamp glass microelectrodes were filled with $3 \mathrm{~N} \mathrm{KCl}$ solutions and pulled to a resistance of $0.5-5 \mathrm{M} \Omega$. The recording solutions used to perfuse the oocytes consisted of room temperature $\mathrm{Ca}^{2+}$-Ringer's at $\mathrm{pH} 4.5,5.0,5.5$, 6.0, or 7.6 as indicated in the Figure legends. Perfusion was controlled by gravity at a rate of $\sim 6 \mathrm{ml} / \mathrm{min}$. Data acquisition and analysis were recorded and stored digitally (MacLab 2e interface) using MacLab v. 3.4 (AD Instruments). $I-V$ relationships were determined using voltageramp protocols: oocyte membrane potential was held at $-40 \mathrm{mV}$ with voltage ramp $(-120$ to $+60 \mathrm{mV})$ applied over $10 \mathrm{sec}$. $\left[{ }^{3} \mathrm{H}\right] 5 \mathrm{HT}$ uptake in SERT-expressing oocytes was performed in $\mathrm{Ca}^{2+}$-Ringer's containing $20 \mathrm{nM}\left[{ }^{3} \mathrm{H}\right] 5 \mathrm{HT}, 100 \mu \mathrm{M}$ pargyline, and $100 \mu \mathrm{M} \mathrm{L}$-ascorbic acid for $30 \mathrm{~min}$ at room temperature. Nonspecific uptake was determined by assaying uninjected or water-injected oocytes in parallel with the wild-type rSERT- and D98E-injected oocytes.

\section{RESULTS}

\section{The conserved Asp in TMD I of the monoamine transporters is critical for transport activity and ion dependence}

Transporter chimeras and species-scanning mutagenesis studies (Barker and Blakely, 1996) have identified residues within SERT TMDs I (Barker et al., 1998) and XII (Barker et al., 1994; Barker and Blakely, 1996) that participate in competitive antagonist recognition. In evaluation of a TMD I residue (Y95 in hSERT and rSERT) that participates in SERT antagonist recognition (Barker et al., 1998), we recognized that this residue was one helical turn below a biogenic amine transporter-specific acidic residue (D98 in SERTs) (Fig. $1 A$ ) that had been implicated in substrate recognition (Kitayama et al., 1992). All other members of the gene family (e.g., GABA, glycine, proline transporters) possess a Gly $(\mathrm{G})$ in the equivalent position, a binary option that may suggest a constrained role in transport function. Mutation of the TMD I Asp residue in the DA transporter (DAT) leads to a disruption of DA transport and cocaine analog recognition (Kitayama et al., 1992). On the basis of the proposed role of a conserved Asp residue in TMD III of adrenergic receptors for coordinating the binding of the amine side chain of catecholamines (Strader et al., 1989, 1991) and the absolute conservation of this residue in monoamine neurotransmitter transporters, Kitayama et al. (1992) hypothesized that this residue coordinates interactions with the protonated alkylamine of substrates. Lacking from the previous studies, however, is evidence of complementarity between sites mutated in the transporter and functional substitutions on substrates or antagonists that can enhance arguments for direct ligand/transporter interactions.

To test whether the conserved Asp in TMD I (Fig. $1 A$ ) plays a critical and general role in biogenic amine transporter function, we introduced several mutations at this position in both rSERT (D98) and hNET (D75). Analysis of radiolabeled neurotransmitter uptake after transient expression of SERT D98 or NET D75 mutants revealed that most mutations completely abolished transport activity, including the switch to Gly generated to mimic the natural deviation in other family members (Fig. $1 B, C$ ). The more conservative mutation D75E in hNET was also nonfunctional, but strikingly the rSERT D98E mutant retained 35-50\% of wildtype rSERT activity. This retention of transport function allowed us to characterize properties of the D98E mutant that were inaccessible in the other substitutions. Thus we found that transient expression of rSERT D98E in both HeLa (data not shown) and COS-7 cells (Fig. 1D, Table 1) reduced 5HT transport capacity $\left(V_{\max }\right)$ by $\sim 50 \%$ with little or no change in the $5 \mathrm{HT} K_{\mathrm{m}}$ value.

To determine whether the reduced $V_{\max }$ values obtained for the D98E mutant in COS-7 cells was caused by reduced translation or surface expression of mutant transporters, immunoprecipitation and cell-surface biotinylation experiments were performed (Melikian et al., 1996; Ramamoorthy et al., 1998). All hNET and rSERT mutants were found to be synthesized at equivalent levels as assessed by immunoprecipitations of $\left[{ }^{35} \mathrm{~S}\right]$-labeled cell extracts (data not shown). Direct immunoblots of rSERT-transfected and rSERT mutant-transfected COS-7 cells validated no differences in steady-state protein levels (Fig. $2 A$ ). SERT and immunoreactive proteins in COS-7 cells are revealed as two bands of 95 and $105 \mathrm{kDa}$ for both the wild-type and $\mathrm{D} 98 \mathrm{E}$ construct that are absent from vector-transfected cells. The two bands, we suspect, represent migration attributable to heterogeneous glycosylation 
A

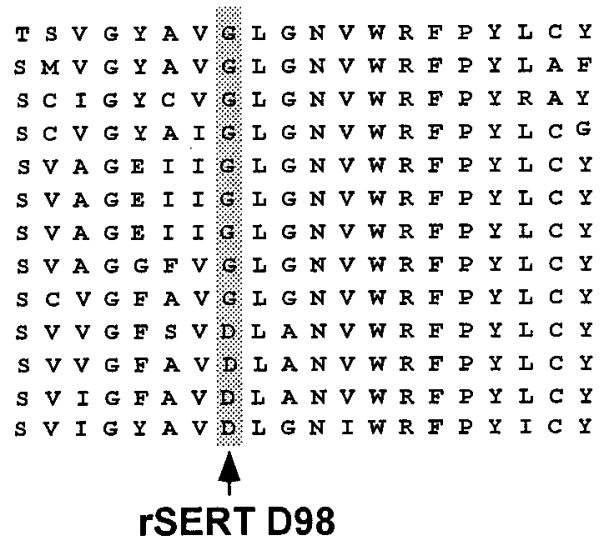

C

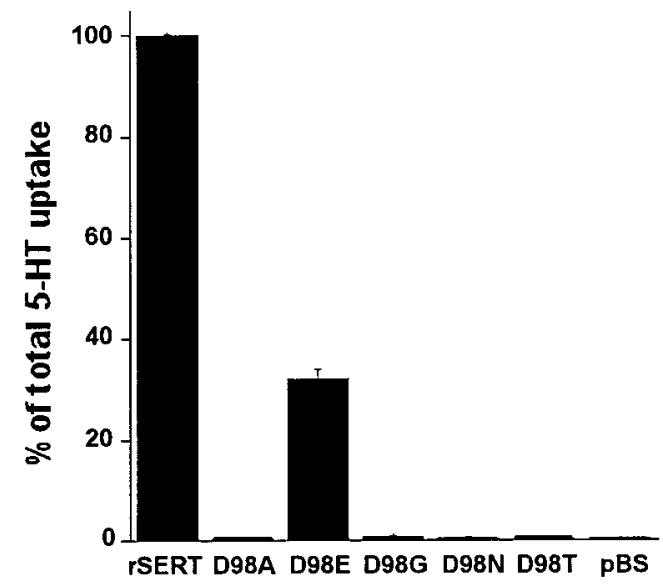

B

rGLYT1a

IGLYT2

IPROT

rGAT1

rGAT2

rGAT3

cBETAINE

TTAURINE

rbCREAT

fET

hNET

hDAT

rSERT
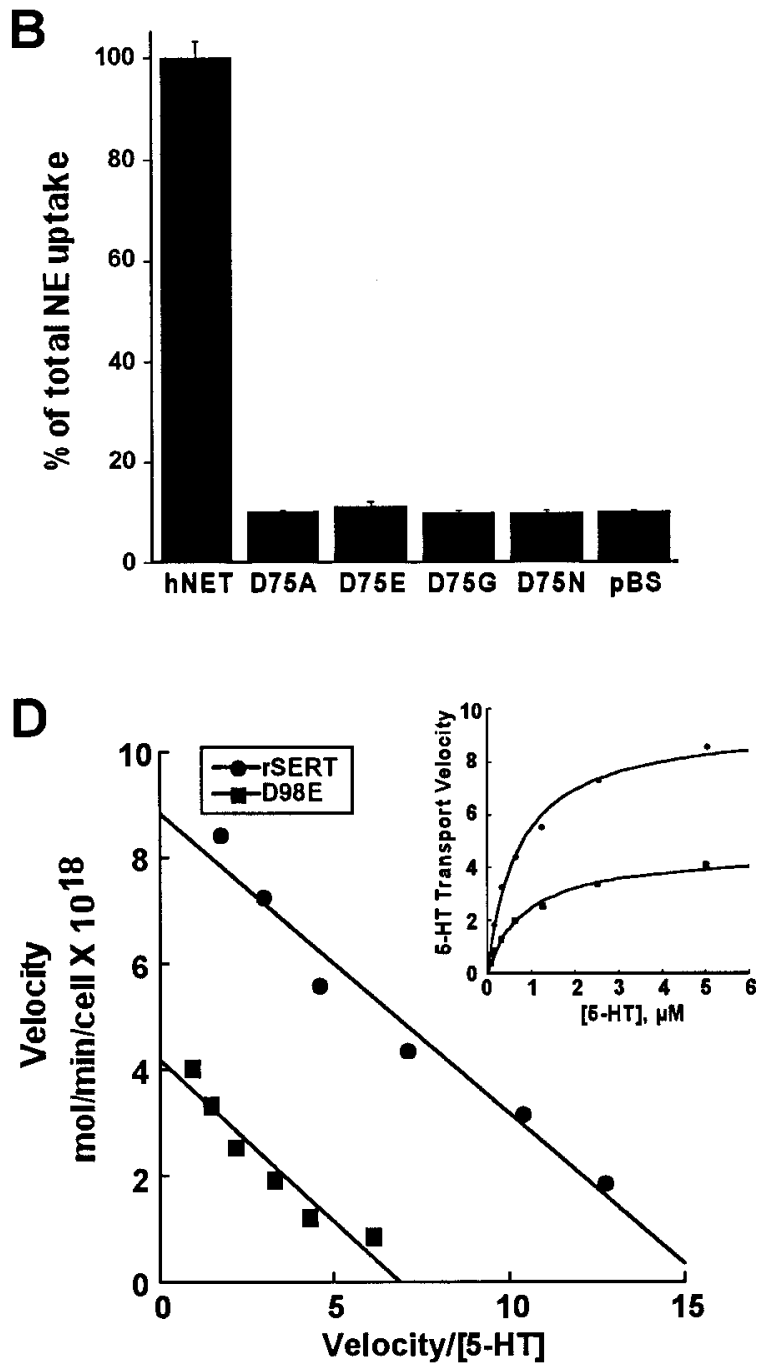

Figure 1. TMD I Asp mutants alter transport activity. A, Amino acid sequence alignment of TMD I from various members of the sodium-dependent transporter gene family. The position of the Asp residue conserved in the biogenic amine transporters is shaded. All other members of the gene family possess a glycine in this position. $r G L Y T$, Rat glycine transporter; $r P R O T$, rat proline transporter; $r G A T$, rat GABA transporter; $c B E T A I N E$, canine betaine transporter; $r b C R E A T$, rabbit creatine transporter; $f E T$, frog epinephrine transporter. $B$, Determination of $\left[{ }^{3} \mathrm{H}\right] \mathrm{NE}$ uptake activity of wild-type hNET, D75A, D75E, D75G, and D75N. Transfected HeLa cells were incubated with $\left.50 \mathrm{~nm} \mathrm{[}{ }^{3} \mathrm{H}\right] \mathrm{NE}$ for 10 min as described in Materials and Methods. Data are presented as percentage of total uptake for wild-type hNET. Nonspecific uptake was determined in HeLa cells transfected with the parent vector pBluescript SK II $(-)(p B S)$. Data represent means \pm SEM of three experiments performed in triplicate. $C$, Determination of $\left[{ }^{3} \mathrm{H}\right] 5 \mathrm{HT}$ uptake activity of wild-type rSERT, D98A, D98E, D98G, D98N, and D98T. Transfected HeLa cells were incubated with $50 \mathrm{~nm}\left[{ }^{3} \mathrm{H}\right] 5 \mathrm{HT}$ for $10 \mathrm{~min}$ as described in Materials and Methods. Data are presented as percentage of total uptake for wild-type rSERT. Nonspecific uptake was determined in HeLa cells transfected with the parent vector pBluescript SK II $(-)(p B S)$. Data represent means \pm SEM of three experiments performed in triplicate. $D$, Saturation kinetics for $\left[{ }^{3} \mathrm{H}\right] 5 \mathrm{HT}$ uptake for wild-type rSERT $(\bullet)$ and rSERT D98E mutant $(\boldsymbol{\square})$. Transfected COS-7 cells were incubated for 10 min with increasing concentrations of $\left[{ }^{3} \mathrm{H}\right] 5 \mathrm{HT}$ as described in Materials and Methods. Data plotted represent means of duplicate determinations and are representative of three separate experiments. Mean $K_{\mathrm{m}}$ and $V_{\max }$ values are given in Table 1. Saturation plots (inset) were converted to Eadie-Hofstee transformations showing a reduced $V_{\max }$ value with no change in $K_{\mathrm{m}}$ value for the D98E mutant.

(Qian et al., 1995), although we did not explore this in detail. Both isoforms were collected from biotinylated cell fractions that are depleted of the intracellular marker calnexin (Fig. 2A) and thus appear to be expressed on the cell surface. When normalized to total calnexin content, no change was evident in D98G surface levels, whereas a small but insignificant decrease in surface SERT protein for the D98E mutant was detected. Wild-type levels of synthesis and cell-surface expression were also seen for the hNET D75E (Fig. 2B) and D75G mutants (data not shown), demonstrating that a disruption of protein stability and/or trafficking cannot account for the loss of transport capacity observed in hNET D75 or rSERT D98 mutants.
Another property of SERTs that might be compromised by D98E and explain a loss of transport capacity is an alteration in $\mathrm{Na}^{+}$or $\mathrm{Cl}^{-}$recognition that provides for energetic coupling to drive 5HT influx. Complete substitution for $\mathrm{Na}^{+}$using lithium or NMDG or for $\mathrm{Cl}^{-}$with gluconate and nitrate salts resulted in a full loss of 5HT transport for both SERT-transfected and SERT D98E-transfected cells (data not shown), revealing a retention of ion dependence for amine uptake. However, when we titrated $\mathrm{Na}^{+}$with NMDG or $\mathrm{Cl}^{-}$with gluconate, we found that SERT D98E exhibited a markedly altered ion dependence (Table 1). As described previously (Rudnick and Clark, 1993; Gu et al., 1994), $\mathrm{Na}^{+}$concentration-dependence data for rSERT could be fit to a 
Table 1. Pharmacological characterization of wild-type rat SERT and D98E mutant

\begin{tabular}{lcc} 
& \multicolumn{2}{c}{5 -HT uptake } \\
& $K_{\mathrm{i}}$ or $K_{\mathrm{m}}(\mathrm{nM}$ unless otherwise indicated $)$ \\
\cline { 2 - 3 } Drug & rSERT & D98E \\
\hline Paroxetine & $0.3 \pm 0.09$ & $0.5 \pm 0.14$ \\
Mazindol & $272 \pm 63$ & $231 \pm 62$ \\
Cocaine & $390 \pm 50$ & $1490 \pm 60^{a}$ \\
Imipramine & $38 \pm 8$ & $190 \pm 70$ \\
Citalopram & $2.2 \pm 0.5$ & $270 \pm 90^{a}$ \\
$5-\mathrm{HT}^{b}$ & $460 \pm 210$ & $400 \pm 160$ \\
$\mathrm{Na}^{+}$ & $19.9 \pm 2.3 \mathrm{~mm}$ & $>100 \mathrm{mM}^{a}$ \\
$\mathrm{Cl}^{-}$ & $5.2 \pm 1.6 \mathrm{~mm}$ & $41.3 \pm 2.5 \mathrm{~mm}^{-}$
\end{tabular}

$K_{\mathrm{i}}$ and $K_{\mathrm{m}}$ values for various compounds for $\left[{ }^{3} \mathrm{H}\right] 5 \mathrm{HT}$ uptake in HeLa cells transiently transfected with wild-type rSERT or the D98E mutant. [ $\left.{ }^{3} \mathrm{H}\right] 5 \mathrm{HT}$ uptake experiments were performed as described in Materials and Methods. Data represent means \pm SEs from results of three experiments performed in triplicate.

${ }^{a} p<0.05$, compared with rSERT value.

${ }^{b} V_{\max }$ values ( $\mathrm{mol} / \mathrm{min}$ per cell) for 5 -HT transport determined in COS-7 cells were rSERT, $5.0 \pm 2.4 \times 10^{-18}$ and D98E, $2.4 \pm 1.2 \times 10^{-18}$.

single hyperbolic function, consistent with a $1 \mathrm{Na}^{+} / 15 \mathrm{HT}$ coupling stoichiometry. In contrast, $\mathrm{Na}^{+}$dependence for D98E did not saturate in an isotonic substitution range, yielding a $K_{\mathrm{m}}$ value we could only estimate as $\geq 100 \mathrm{~mm}$ (vs $\sim 20 \mathrm{~mm}$ for rSERT). $\mathrm{Cl}^{-}$ dependence for either rSERT or rSERT D98E could be fit to a single hyperbolic function as reported previously ( $\mathrm{Gu}$ et al., 1994), supportive of a $1 \mathrm{Cl}^{-} / 15 \mathrm{HT}^{+}$coupling stoichiometry. However, in rSERT D98E we found an eightfold increase in the $\mathrm{Cl}^{-} K_{\mathrm{m}}$ value. These findings indicate that the D98E mutation compromises utilization of external $\mathrm{Na}^{+}$and $\mathrm{Cl}^{-}$for catalyzing inward 5HT transport, effects that may explain the reduction in $5 \mathrm{HT}$ transport capacity in the face of little or no reduction in surface expression or alteration in $5 \mathrm{HT} K_{\mathrm{m}}$ value.

\section{D98E differentially alters antagonist potency}

Pharmacological characterization of the rSERT D98E mutant by $\left[{ }^{3} \mathrm{H}\right] 5 \mathrm{HT}$ transport inhibition experiments revealed selective alterations in SERT antagonist potencies (Table 1). Thus, paroxetine and mazindol potency were essentially equal at both wildtype rSERT and D98E mutant. Cocaine and imipramine exhibited a three- to fivefold reduction in potency. Of the SSRIs tested, citalopram potency was most severely affected, with a 100 -fold loss of potency at the rSERT D98E mutant. We confirmed these effects using [ $\left.{ }^{125} \mathrm{I}\right]$ RTI-55-labeled competition binding experiments (Boja et al., 1992; Wall et al., 1993). RTI-55 is a substituted phenyltropane like cocaine, and its $K_{\mathrm{d}}$ value for binding to SERT was significantly increased at D98E (0.37 nм vs 3.7 $\mathrm{nM})$ as were the $K_{\mathrm{i}}$ values of cocaine $(133 \pm 35 \mathrm{nM}$ vs $580 \pm 160$ $\mathrm{nm})$ and imipramine (11.2 $\pm 2 \mathrm{~nm}$ vs $94 \pm 34 \mathrm{~nm})$. Interestingly, in these assays 5HT displayed a sixfold loss of affinity as an inhibitor of $\left[{ }^{125}\right.$ I]RTI-55 binding (184 $\pm 40 \mathrm{~nm}$ vs $\left.1160 \pm 130 \mathrm{nM}\right)$, suggesting that $5 \mathrm{HT}$ recognition is subject to conformational accommodations of 5HT or SERT or both under the conditions used for transport. Alternatively, kinetic terms besides 5HT binding that can influence the $K_{\mathrm{m}}$ value (Rudnick, 1998b) may have been perturbed by D98E, offsetting affinity losses. [ $\left.{ }^{125} \mathrm{I}\right] \mathrm{RTI}-55$ $B_{\text {max }}$ values were equivalent for rSERT and rSERT D98E, consistent with no major loss in SERT protein expression induced by the mutation.

\section{Selective effects of D98E on substrate recognition}

The previous proposal (Kitayama et al., 1992) that amine substrate recognition involves ion pairing between the Asp side chain carboxylic acid and the positively charged amine group on amine substrates, as in G-protein-coupled amine receptors (Strader et al., 1989, 1991), suggests that mutations at D98 of rSERT might be offset by specific structural modifications of 5HT or analogs, in particular modifications of the alkylamine chain extending from the indole ring. We identified two 5HT derivatives, dimethyltryptamine (DMT) and gramine (Fig. $3 A$ ), that differ only in the length of their amine-containing side chain. If the ethylamine of DMT interacts with the carboxylic acid at D98 (Fig. $3 A$ ), shortening the alkylamine chain by one carbon to yield gramine should disrupt this interaction and lead to lower potency inhibition of 5HT uptake (Fig. 3B); however, gramine should reestablish this ion pair if the carboxylic acid at D98 is lengthened by one carbon as in the D98E mutation (Fig. 3C). When the potencies of DMT and gramine for inhibition of 5HT uptake were compared at the wild-type rSERT and the D98E mutant, we found that DMT interacts with both the wild-type and mutant transporter equivalently (Fig. 3D, Table 2). The shorter-chain gramine is more than one order of magnitude weaker than DMT as a 5HT uptake inhibitor at wild-type rSERT (Fig. 3D, Table 2). Remarkably, gramine became a more potent inhibitor of 5HT uptake when tested on SERT D98E, a potency indistinguishable from DMT or 5HT at wild-type rSERT (Fig. 3D, Table 2). The preference of the D98E mutant for the shorter methylamine derivative was selective in that other substitutions on the tryptamine structure (e.g., 5'-OH, indole $\mathrm{N}$, alkylamine methylation) were insensitive to the increased chain length associated with the D98E mutation (Table 2). Furthermore, we sought other structures that might generalize an interaction of the alkylamine side chain with the carboxylic acid at rSERT D98. DA and its methylamine derivative dihydroxybenzylamine (DHBA) are weak inhibitors of 5HT uptake relative to the tryptamines; however, they present a similar opportunity to adjust the alkylamine side chain length by one carbon and test for a gain of function to the D98E mutation. We found that DHBA is more than one order of magnitude less potent than DA at inhibiting 5HT uptake by wild-type rSERT, whereas the two compounds are comparable in potency at the D98E mutant because of a reduced potency of DA and a gain of function for DHBA (Table 2).

\section{rSERT D98E disrupts substrate-gated ion flow}

To gain further insights into the functional impact of the D98E mutation and its interaction with tryptamine derivatives, we examined substrate-induced currents in voltage-clamped Xenopus oocytes. Electrophysiological measurements in transporterexpressing oocytes have demonstrated that substrates, but not antagonists, activate transporter-associated currents (Mager et al., 1994; Sonders et al., 1997), and we used this facet of SERT behavior instead of conventional $\left[{ }^{3} \mathrm{H}\right]$ substrate flux measurements because of the lack of commercial availability of $\left[{ }^{3} \mathrm{H}\right] \mathrm{DMT}$ or $\left[{ }^{3} \mathrm{H}\right]$ gramine. Consistent with previous reports (Mager et al., 1994), saturating concentrations of 5HT induced an inward current at $\mathrm{pH} 7.6$ in oocytes expressing the wild-type rSERT voltage clamped at $-80 \mathrm{mV}$ (Fig. $4 A$ ). These currents are blocked by imipramine and are absent from uninjected oocytes. Surprisingly, the D98E mutant demonstrated little $(<2 \mathrm{nA})$ to no measurable 5HT-induced current at pH 7.6 (Fig. 4B). This was remarkable because $\left[{ }^{3} \mathrm{H}\right] 5 \mathrm{HT}$ uptake activity for the D98E mutant assayed in the same batches of oocytes used for voltage-clamp experiments 

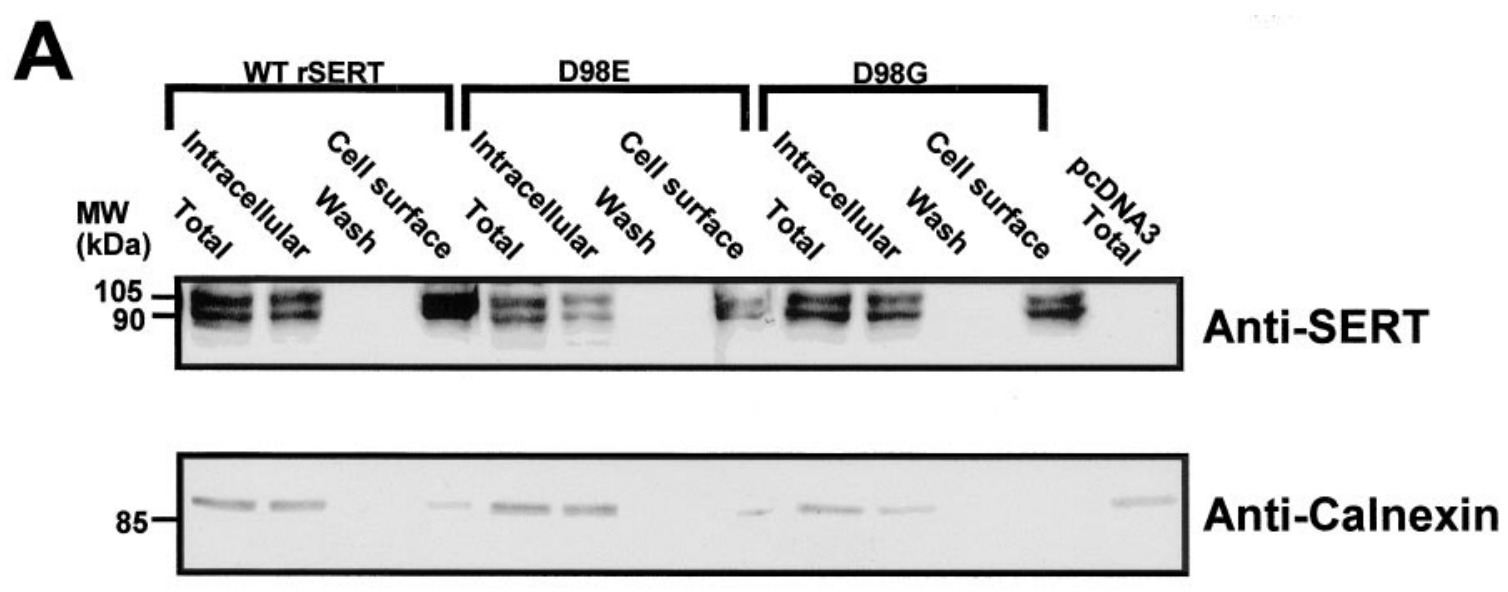

B

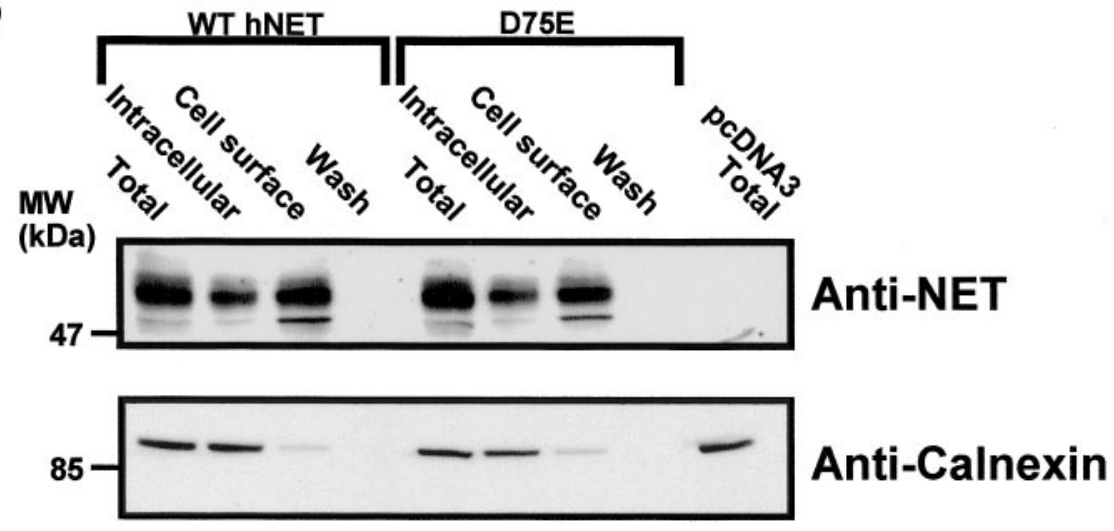

Figure 2. SERT and NET TMD I Asp mutants do not alter transporter cell-surface expression. COS-7 cells were transfected with rSERT, D98E, D98G, or pcDNA3 vector (control), and cell-surface biotinylation experiments were performed as described in Materials and Methods. $A$, Immunoblots identifying rSERT and rSERT mutants using SERT-specific antibody CT-2B (Qian et al., 1995). B, Immunoblots identifying hNET and hNET D75E mutant using NET-specific antibody (Melikian et al., 1994). After blots were probed with the anti-SERT or anti-NET antibodies, membranes were stripped and reprobed with anti-calnexin antibody (StressGen). Because calnexin is a endoplasmic reticulum transmembrane protein, it is a marker for intracellular proteins. Low levels of calnexin bands $(<0.5 \%$ of total) were detectable in the cell-surface lanes, suggesting only minor contamination of biotinylated (cell surface) fractions with intracellular proteins. Density of bands was determined using scanning densitometry (ImageQuant, Molecular Dynamics) with SERT total fractions normalized to total calnexin immunoreactivity. Data presented are representative of three separate experiments.

was reduced only $\sim 40 \%$ as compared with wild-type rSERT (Fig. $4 C$ ), similar to findings in COS-7 cells. Lowering buffer $\mathrm{pH}$ from 7.6 enhanced both a leak current as well as 5HT-induced currents (Cao et al., 1997). We retested rSERT and D98E at pH 5.0 and found that both transporters exhibited increased leak currents (see below), and we were able to significantly increase 5HT-gated currents in the wild-type transporter (Fig. 4A). Moreover, acidic medium $\mathrm{pH}$ allowed us to uncover substrate-gated ion flow in the SERT D98E (Fig. 4B). At pH 5.0, we confirmed that 5HT and DMT, as well as gramine, induce currents in the D98E mutant, indicating that all three compounds behave as substrates for the transporter. Consistent with this notion, imipramine (Fig. 4A,B) blocked all substrate-induced currents in D98E-injected oocytes tested at $\mathrm{pH} 5.0$ and revealed an outward current presumably attributable to block of a substrate-independent inward leak (Mager et al., 1994). Thus both wild-type rSERT and rSERT D98E are expressed in the oocyte, but acidic $\mathrm{pH}$ is required to reveal substrate-induced currents for D98E. This does not occur because acidic $\mathrm{pH}$ allows substrates to permeate more readily because the shift to $\mathrm{pH} 5.0$ actually diminishes 5HT transport activity more for D98E than for rSERT (Fig. 4C), suggesting that
D98E perturbs the transporter's charge movement/substrate flux ratio.

The presence of DMT- and gramine-induced currents in D98E-expressing oocytes (measured at pH 5.0) allowed us to seek evidence for a shift in gramine $K_{\mathrm{m}}$ value as a transported substrate as predicted by the 5 HT uptake inhibition studies reported in COS-7 cells. Thus we measured inward currents at $\mathrm{pH} 5.0$ induced by increasing concentrations of gramine in oocytes expressing either wild-type rSERT or the D98E mutant (Fig. $5 A$ ). In both cases, gramine-induced currents were saturable and fit readily with single hyperbolic functions. Analyses of these fits revealed a sevenfold increase in the potency (decreased $K_{\mathrm{m}}$ value) for gramine-activated currents at the D98E mutant $(0.3 \pm 0.04$ $\mu \mathrm{M})$ as compared with wild-type rSERT $(2.2 \pm 0.4 \mu \mathrm{M})$. Thus, gramine is more potent at the D98E mutant in both 5HT transport inhibition assays and in activation of substrate-dependent ion flow. At saturating concentrations at $\mathrm{pH}$, gramine and 5HT gated equivalent levels of whole-cell current $\left(I_{\max }\right)$ for the D98E mutant, whereas gramine was less efficacious than $5 \mathrm{HT}$ at wildtype rSERT (Fig. $5 B$ ). This indicates that gramine is not only a more potent substrate for the D98E mutant, but also D98E shifts 


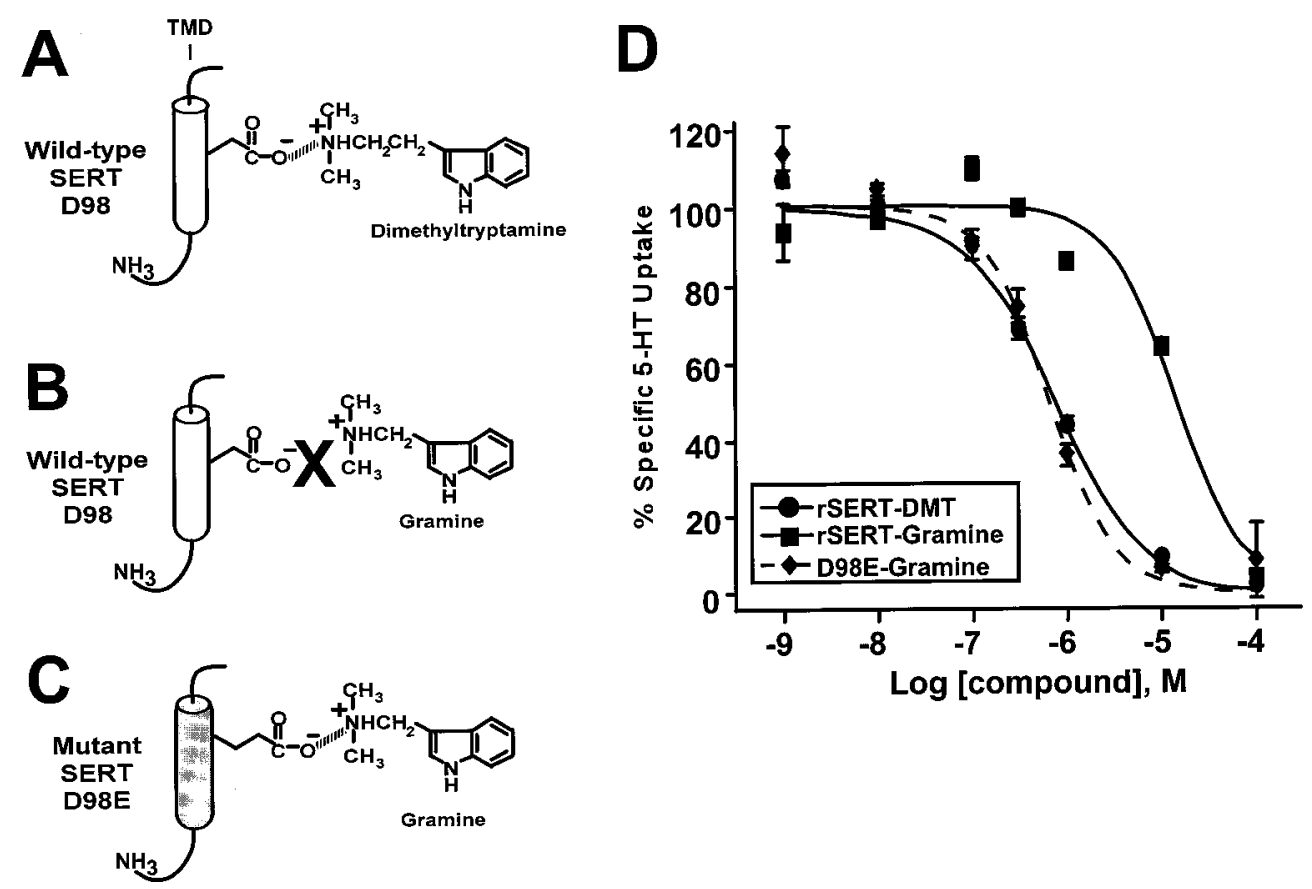

Figure 3. Structure-activity studies with tryptamine derivatives and the rSERT D98E mutant implicate a direct interaction between neurotransmitter and D98. A, Proposed model for interactions between carboxylic acid of SERT D98 and tryptamine alkylamine group. B, Disruption of carboxylic acid-amine interaction by shortening DMT to the methylamine structure gramine. $C$, Reestablishing carboxylic acid-amine interactions by lengthening carboxylic acid alkyl chain by one methyl group (D98E) combined with shorter methylamine substrate gramine. $D$, Evaluation of DMT and gramine potency for inhibition of $\left[{ }^{3} \mathrm{H}\right] 5 \mathrm{HT}$ uptake at wild-type rSERT and D98E mutant. $\left[{ }^{3} \mathrm{H}\right] 5 \mathrm{HT}$ uptake assays were performed with transiently transfected COS-7 cells as described in Materials and Methods, with increasing concentrations of DMT or gramine added simultaneously with the addition of $10 \mathrm{~nm}\left[{ }^{3} \mathrm{H}\right] 5 \mathrm{HT}$. Nonspecific uptake was determined in COS-7 cells transfected with the parent vector pcDNA3 and subtracted from total values. Data were plotted as percentage of specific $5 \mathrm{HT}$ uptake. All data plotted represent means \pm SEM of triplicate determinations and are representative of three separate experiments. Apparent $K_{\mathrm{i}}$ values are presented in Table 2.

Table 2. Comparison of monoamine derivatives for 5HT uptake inhibition at wild-type rat SERT and D98E mutant

\begin{tabular}{lcc} 
& \multicolumn{1}{c}{$K_{\mathrm{i}}(\mu \mathrm{M})$} & \\
\cline { 2 - 3 } Compound & rSERT & D98E \\
\hline 5-Hydroxytryptamine & \\
Dimethyltryptamine & $0.46 \pm 0.21$ & $0.40 \pm 0.16$ \\
Gramine & $0.74 \pm 0.05$ & $0.44 \pm 0.23$ \\
Dopamine & $10.3 \pm 2.0$ & $0.81 \pm 0.14^{b}$ \\
Dihydroxybenzylamine & $240 \pm 57$ & $830 \pm 335$ \\
5-Methyltryptamine & $4100 \pm 1100$ & $930 \pm 110^{b}$ \\
Tryptamine & $6.0 \pm 0.9$ & $7.1 \pm 0.8$ \\
$N 1$-isopropyltryptamine & $0.85 \pm 0.1$ & $0.55 \pm 0.1$ \\
& $36 \pm 6.3$ & $19 \pm 4.7$
\end{tabular}

$\overline{K_{\mathrm{i}} \text { values for the inhibition by various compounds of }\left[{ }^{3} \mathrm{H}\right] 5 \mathrm{HT} \text { uptake in COS-7 cells }}$ transiently transfected with wild-type rSERT or the D98E mutant. $\left[{ }^{3} \mathrm{H}\right] 5 \mathrm{HT}$ uptake experiments were performed as described in Materials and Methods. Data represent means \pm SEs from results of three to six experiments performed in triplicate.

${ }^{a} K_{\mathrm{m}}$ values from Table 1.

${ }^{b} p<0.05$, compared with wild-type rSERT value.

the relative efficiency of gramine to gate substrate-activated currents to a level comparable to that observed for $5 \mathrm{HT}$.

\section{A change in ion selectivity induced by rSERT D98E}

The lack of detectable substrate-gated currents for the rSERT D98E mutant at pH 7.6 (Fig. 4B) despite significant 5HT uptake in unclamped oocytes and changes in charge/substrate flux ratios suggested a mutation-induced disruption in a specific aspect of 5HT-gated ionic permeation. $\mathrm{Na}^{+}$is involved in gating inward current flow (Mager et al., 1994) and has been proposed as the major charge-carrying species in the leak pathway at neutral $\mathrm{pH}$ (Lin et al., 1996). Protons appear to readily permeate biogenic amine transporters in the absence of amine substrates (Sonders et al., 1997) and may also contribute to the substrate-gated current at acidic extracellular $\mathrm{pH}$ (Cao et al., 1997). We thus asked whether D98E alters $\mathrm{Na}^{+}$or $\mathrm{pH}$ dependence or both for leak or substrate-activated currents. As described previously (Mager et al., 1994; Cao et al., 1997; Galli et al., 1997), $\mathrm{Na}^{+}$dependence of 5HT-activated inward currents was evident when NMDG was substituted for $\mathrm{Na}^{+}$on wild-type rSERT at pH 7. 6. At pH 5.0, where 5HT-activated currents can be detected in rSERT D98E, we found a similar loss of currents on $\mathrm{Na}^{+}$substitution (Fig. $6 A, B)$. Thus, as with 5 HT transport activity measured in COS-7 cells, a dependence on extracellular $\mathrm{Na}^{+}$for gating nonstoichiometric ion flow is retained in the D98E mutant. 5HT application to rSERT-injected or rSERT D98E-injected oocytes in NMDG buffer revealed outward currents (Fig. 6A,B), consistent with $\mathrm{Na}^{+}$-independent 5HT binding to SERTs (Mager et al., 1994; Cao et al., 1997; Galli et al., 1997) and $\mathrm{H}^{+}$permeation of a leak pathway that 5HT can block (Cao et al., 1997) and that appears to be intact in the D98E mutant.

If acidic medium is required to detect substrate-activated currents for the D98E mutant in $\mathrm{Na}^{+}$buffer, decreased $\mathrm{pH}$ may titrate residues that restore $\mathrm{Na}^{+}$permeation through substrateactivated channels, or protons may simply be traversing this pathway. To explore these possibilities, leak and 5HT-gated currents carried by rSERT (Fig. 7A) and rSERT D98E (Fig. 7B) were studied in Xenopus oocytes as a function of extracellular medium $\mathrm{pH}$. $I-V$ curves were determined by ramp protocols during sequential perfusion with buffer $(\mathrm{Ctrl})$, substrate $(5 H T, 5 \mu \mathrm{M})$, or antagonist [citalopram (Cit), $30 \mu \mathrm{M}$ ]. Initial experiments were conducted at $\mathrm{pH} 5.0$ where $5 \mathrm{HT}$ can be shown to gate both wild-type rSERT and rSERT D98E currents (Fig. 4A,B). The application of citalopram to injected oocytes in the absence of 5HT (but not uninjected oocytes; data not shown) resulted in positive (outward) currents below $-30 \mathrm{mV}$. The shapes of the subtracted $I-V$ plots were similar comparing mutant and wildtype SERTs (data not shown). The reversal potential for these currents $\left(I_{\mathrm{Cit}}-I_{\mathrm{Ctrl}}\right)$ was unmodified by the D98E mutation (wildtype rSERT $-12.2 \pm 5.8 \mathrm{mV}$ vs D98E $-6.0 \pm 3.5 \mathrm{mV}$ ). Similarly, 


\section{A Wild-type rSERT}

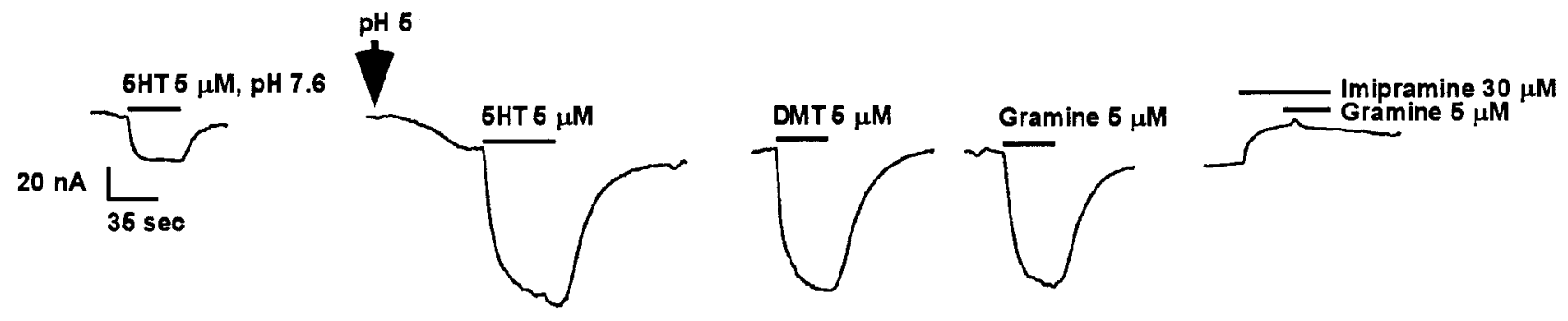

B rSERT D98E Mutant

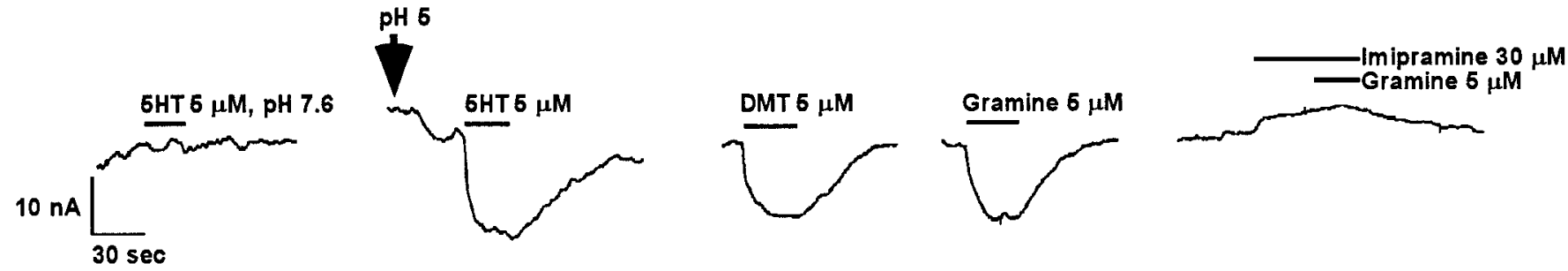

C

pH 7.6

pH 5.0

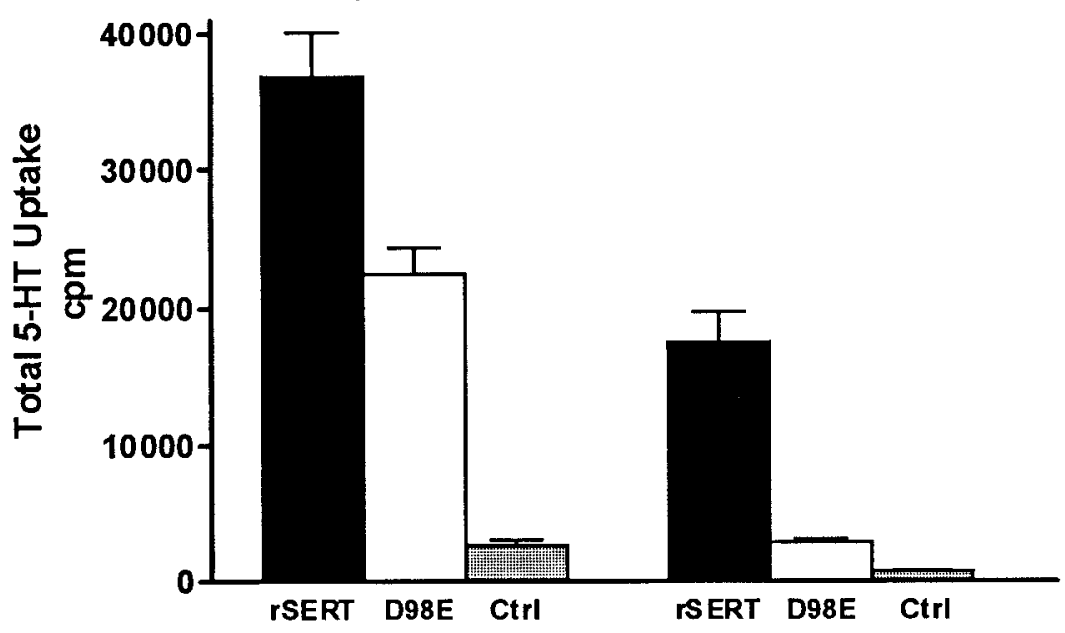

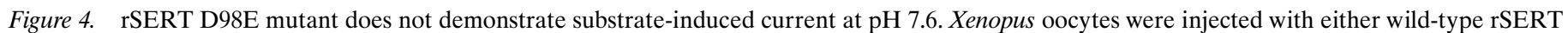

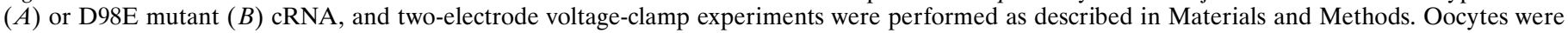

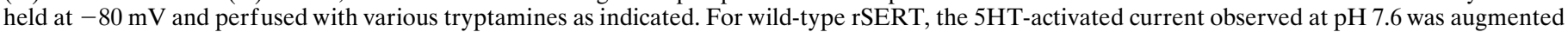

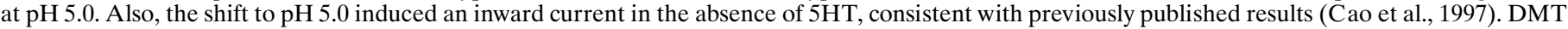

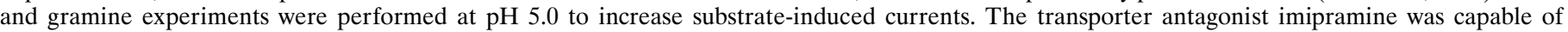

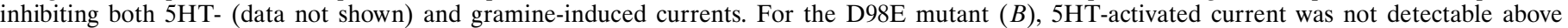

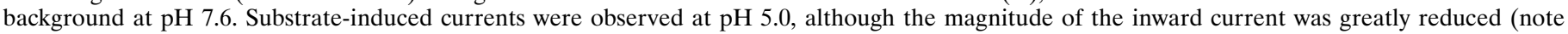

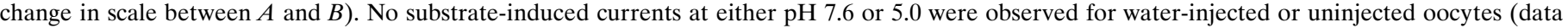

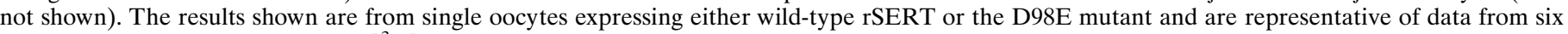

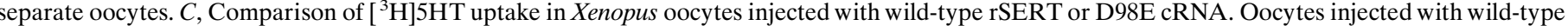

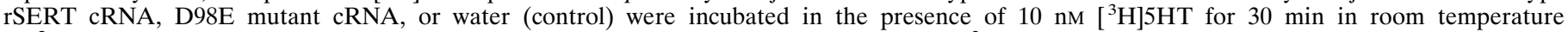
$\mathrm{Ca}^{2+}$-Ringer's, pH 7.6 or 5.0 , as described in Materials and Methods. Data represent total $\left[{ }^{3} \mathrm{H}\right] 5 \mathrm{HT}$ uptake $(\mathrm{cpm})(n=9)$. 
A

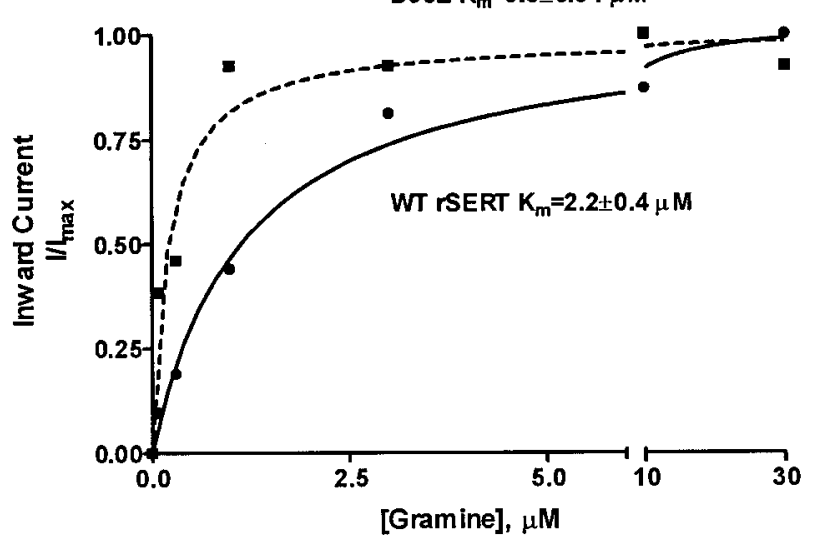

B

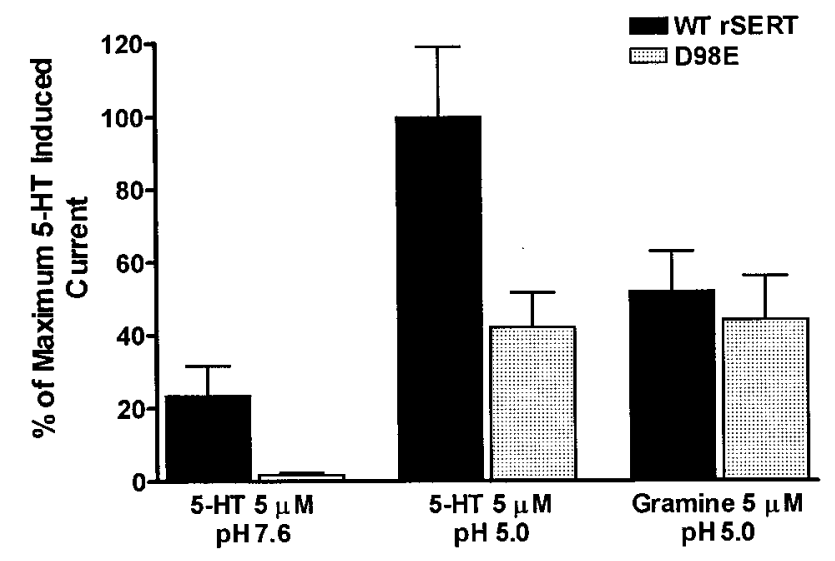

Figure 5. Saturable transporter-associated currents in response to increasing concentrations of gramine. Xenopus oocytes were injected with either wild-type rSERT or D98E mutant cRNA, and two-electrode voltage-clamp experiments were performed as described in Materials and Methods. Oocytes were held at $-80 \mathrm{mV}$ and perfused with increasing concentrations of gramine in $\mathrm{Ca}^{2+}$-Ringer's, $\mathrm{pH}$ 5.0. $A$, Data represent steady-state currents fit to Michaelis-Menten rectangular hyperbole by nonlinear regression (GraphPad Prism) from representative oocytes $(n=$ 7). Mean apparent $K_{\mathrm{m}}$ values: wild-type $\operatorname{rSERT}(\mathbf{O}), 2.2 \pm 0.4 \mu \mathrm{M}$; D98E mutant (ם), $0.3 \pm 0.04 \mu \mathrm{M}$. $B$, Comparison of currents induced by $5 \mathrm{HT}$ (5 $\mu \mathrm{M})$ and gramine $(5 \mu \mathrm{M})$ in $\mathrm{Ca}^{2+}$-Ringer's, $\mathrm{pH} 7.6$ or 5.0. 5HT- and gramine-activated currents in the $\mathrm{D} 98 \mathrm{E}$ mutant at $\mathrm{pH} 7.6$ were barely detectable above background. Data represent percentage of maximum 5HT-induced current observed for wild-type rSERT at pH 5.0.

the effect of $\mathrm{pH}$ change on the reversal potential of the leak current was similar in both wild-type rSERT and the D98E mutant, with slopes of $42 \mathrm{mV} / \mathrm{pH}$ unit and $46 \mathrm{mV} / \mathrm{pH}$ unit, respectively (Fig. $7 C$ ), suggesting that protons carry a significant fraction of current in the leak pathway at pH 5.0 and confirming that $\mathrm{H}^{+}$permeation in the absence of substrate (leak) is unperturbed by the D98E mutation.

The addition of 5HT to transporter-injected oocytes elicited inward currents at all potentials $\left(I_{5 \mathrm{HT}}\right)$, increasing in magnitude relative to $I_{\mathrm{Ctrl}}$ at negative voltages for both wild-type and rSERT D98E. When normalized for maximum current, the shape of the $I_{5 \mathrm{HT}}-I_{\mathrm{Ctrl}}$ plot was similar, indicating a comparable overall voltage dependence to the substrate-activated current (data not shown). However, the $I_{5 \mathrm{HT}}$ profile for D98E was noticeably shifted to the right relative to $I_{5 \mathrm{HT}}$ for wild-type SERT (X intercept at $-18 \mathrm{mV}$ for SERT vs $0 \mathrm{mV}$ for D98E), suggesting a change in the permeant species carrying the substrate-induced current. Because $I_{5 \mathrm{HT}}$ never becomes outward relative to $I_{\mathrm{Ctrl}}$ (Mager et al., 1994; Galli et al., 1995; Sonders et al., 1997), this may reflect the ability of the substrate to induce an inward current at negative potentials and block outward leak currents at positive potentials. Regardless, a true reversal potential for this current (plotted as $I_{5 \mathrm{HT}}-I_{\mathrm{Ctrl}}$ ) cannot be calculated. However, because antagonist blocks both leak and substrate-activated currents, $I_{5 \mathrm{HT}}$ does intersect with $I_{\text {Cit }}$, defining the total composite SERT current arising from substrate occupancy. When $I_{5 \mathrm{HT}}-I_{\mathrm{Cit}}$ was plotted as a function of $\mathrm{pH}$, the reversal potential for wild-type rSERT demonstrated a $28 \mathrm{mV}$ shift per $\mathrm{pH}$ unit change consistent with a partial contribution of $\mathrm{H}^{+}$to $5 \mathrm{HT}$-gated ion flow (Fig. 7D). In contrast, the $\mathrm{D} 98 \mathrm{E}$ mutant exhibited a $53 \mathrm{mV}$ shift in reversal potential per $\mathrm{pH}$ unit change, a value approaching the predicted value for a pure $\mathrm{H}^{+}$-selective current $(58 \mathrm{mV})$. These data suggest that acidic medium does not restore conductance of the same permeant species to D98E that define the substrateactivated current in rSERT. Rather, the acidic extracellular medium appears to provide a source of permeant ions for a channel that, like the leak pathway, is highly permeant to $\mathrm{H}^{+}$.

\section{DISCUSSION}

SERTs, like other members of the $\mathrm{Na}^{+}$-dependent transporter family, are multi-functional proteins. First identified as mediators of 5HT uptake across brain and platelet membranes, SERTs are now recognized as major targets for antidepressants and psychostimulants (Barker and Blakely, 1995). In addition to these transport-associated processes, SERTs have multiple ion channellike conducting states (Mager et al., 1994; Lester et al., 1996; Lin et al., 1996; Galli et al., 1997) that are sensitive to competitive transport antagonists. The structural requirements for substrate recognition, antagonist selectivity and 5HT-gated ion flow are as yet largely undefined and may involve nonoverlapping determinants. Alternatively, neurotransmitter and ion permeation may share a common permeation pathway. Our data indicate that D98 in TMD I of SERT influences antagonist recognition and acts as a selectivity determinant for substrate recognition and substrategated ion flow, linking TMD I to cocaine and antidepressantsensitive permeation pathways for both neurotransmitter and nonstoichiometric ion flow.

Although most mutations at the Asp residue in TMD I for NET and SERT were nonfunctional, rSERT D98E retained significant transport activity, allowing investigation into the role of Asp98 in transporter function. The unaffected potency of several transporter antagonists as well as a wild-type $K_{\mathrm{m}}$ value for 5HT in the D98E mutant supports a lack of mutation-induced perturbations in SERT structure. Our major kinetic finding was reduced 5HT transport capacity $\left(V_{\max }\right)$ that did not appear to arise from reduced translation or surface expression, suggesting inefficient substrate translocation. 5HT can bind to SERTs in the absence of $\mathrm{Na}^{+}$and $\mathrm{Cl}^{-}$(Humphreys et al., 1994), but the amine does not translocate. D98E ion dependence demonstrated a shift of both $\mathrm{Na}^{+}$and $\mathrm{Cl}^{-}$dependence to higher $K_{\mathrm{m}}$ values. The $\mathrm{Na}^{+}$ $K_{\mathrm{m}}$ value for D98E was out of the isotonic range, making quantitative modeling of this perturbation on 5HT uptake difficult. However, using a Na${ }^{+} K_{\mathrm{m}}$ value of $100 \mathrm{~mm}$ and the derived $\mathrm{Cl}^{-}$ $K_{\mathrm{m}}$ value of $40 \mathrm{~mm}$, and assuming monophasic kinetics with no ion interactions, transport capacity should drop to $47 \%$ of control in our standard assay buffer $\left(120 \mathrm{~mm} \mathrm{Na}^{+}, 129.1 \mathrm{mM} \mathrm{Cl}^{-}\right)$, reason- 


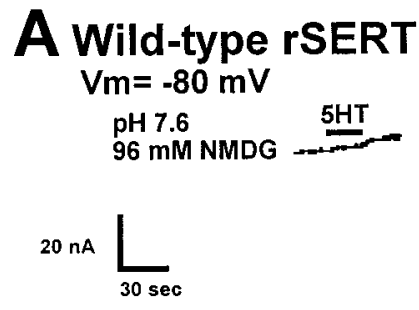

Figure 6. $\mathrm{Na}^{+}$is required for SERT inward currents at $\mathrm{pH}$ 5.0. Xenopus oocytes were injected with either wild-type rSERT $(A)$ or D98E mutant $(B)$ cRNA and two-electrode voltage-clamp experiments performed as described in Materials and Methods. Oocytes were held at $-80 \mathrm{mV}\left(V_{\mathrm{m}}=\right.$ membrane potential $)$ and perfused with 5HT $10 \mu \mathrm{M}$ in the presence or absence of $\mathrm{Na}^{+}$at either pH 7.6 or $5.0 . \mathrm{Na}^{+}$concentration in the $\mathrm{Ca}^{2+}$-Ringer's buffer was isotonically replaced with $N$-methyl-D-glucamine $(N M D G)$. The results shown are from single oocytes expressing either wildtype rSERT or the D98E mutant and are representative of data from three separate oocytes.
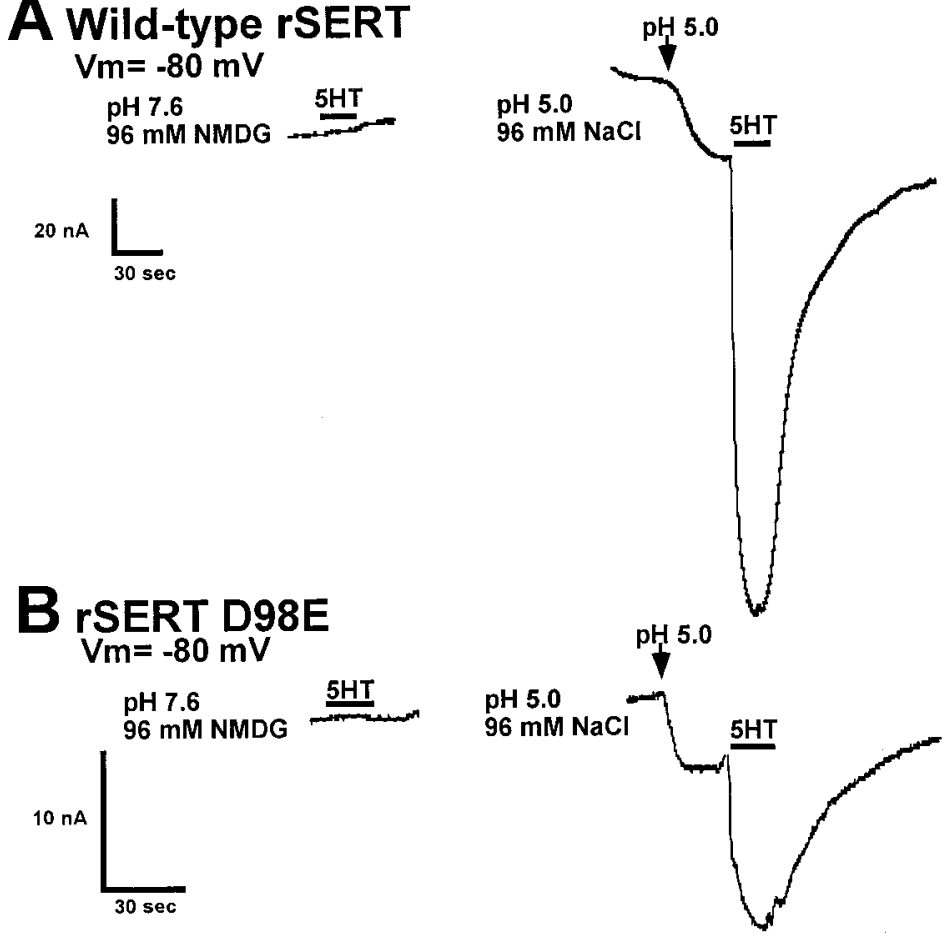

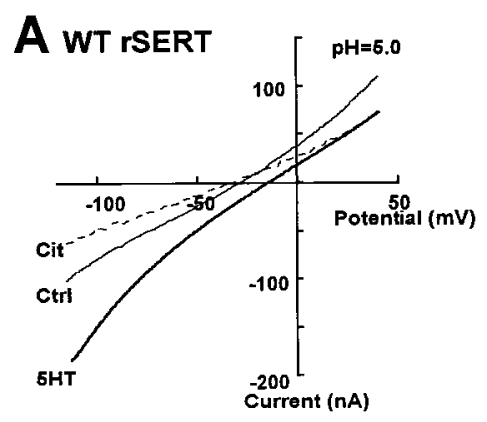

Figure 7. Current-voltage $(I-V)$ relationships for wild-type rSERT and D98E mutant conducting states. Currents were measured in a single voltage-clamped $(-40 \mathrm{mV})$ oocyte during voltage-ramp protocols $(-120$ to $+60 \mathrm{mV}$ in $10 \mathrm{sec})$ in the presence of either buffer (control, Ctrl), 5HT $5 \mu \mathrm{M}$, or the transporter antagonist citalopram $30 \mu \mathrm{M}(\mathrm{Cit}) . \mathrm{A}, I-V$ plots for currents for wild-type rSERT. $B, I-V$ plots for currents for D98E mutant. All experiments were performed at $\mathrm{pH}$ 5.0. Data shown are representative of recordings from single oocytes expressing either wild-type rSERT or D98E mutant $(n=9-12)$. $C$, Effect of $\mathrm{pH}$ on reversal potential of substrateindependent transporter-associated leak current $\left(I_{\mathrm{Ctrl}}-I_{\mathrm{Cit}}\right)$ for rSERT $(\square$, solid line $)$ and D98E mutant $(\boldsymbol{\square}$, dashed line $)$. Data plotted are means \pm SEM $(n=7-9)$ fit to least- square linear regression with slopes of $-42 \mathrm{mV} / \mathrm{pH} \mathrm{U}(r S E R T ; r=$ $0.99)$ and $-46 \mathrm{mV} / \mathrm{pH} \mathrm{U}(D 98 E ; r=0.99)$. $D$, Effect of $\mathrm{pH}$ on reversal potential of $5 \mathrm{HT}$-activated transporter-specific current $\left(I_{5 \mathrm{HT}}-I_{\mathrm{Cit}}\right)$ for $\mathrm{rSERT}(\square$, solid line) and D98E mutant $(\boldsymbol{\square}$, dashed line $)$. Data plotted are means \pm SEM $(n=7-12)$ fit to least-square linear regression with slopes of $-28 \mathrm{mV} / \mathrm{pH}$ $\mathrm{U}(r S E R T ; r=0.99)$ and $-53 \mathrm{mV} / \mathrm{pH} \mathrm{U}(D 98 E ; r=0.98)$.

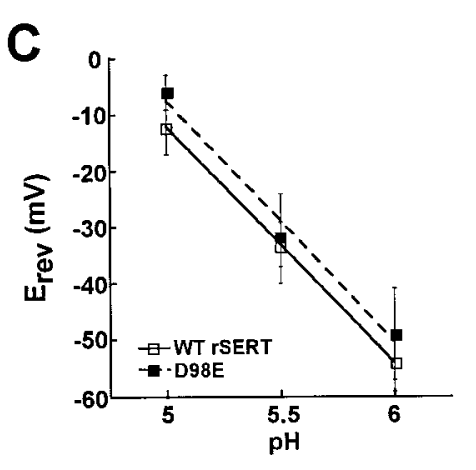

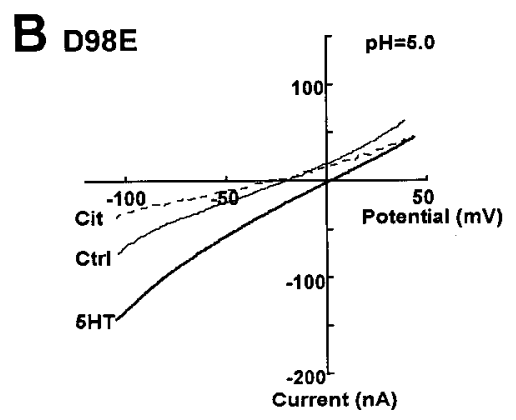

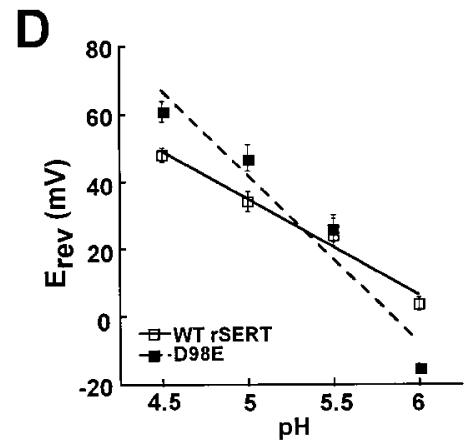

ably close to the measured reduction in COS-7 cells. Our findings suggest that major determinants for both $\mathrm{Na}^{+}$and $\mathrm{Cl}^{-}$coupling reside within TMD I, although we cannot rule out a mutational effect on critical contact sites that lie outside this region. In keeping with a role for TMD I in ion dependence, Mager and coworkers (1996) found disrupted $\mathrm{Na}^{+}$transient currents from mutation of a conserved TMD I tryptophan in GAT1 (W103 in rSERT), and Chen et al. (1997a) noted a cation dependence to methanethiosulfonate inactivation of rSERT C109, a residue in the extracellular loop between TMDs I and II.
Models of $\beta$-adrenergic receptor interactions with catecholamines propose a direct coordination of the positively charged alkylamine of ligands with the negatively charged carboxylic acid of a conserved TMD III Asp (Strader et al., 1991). To support this model, Strader and coworkers (1991) found that catecholamine derivatives could compensate for mutations in the $\beta$-adrenergic receptor. Thus, mutation of the Asp (D113) in TMD III to Ser (D113S), thereby replacing the carboxylic acid with a hydroxyl group, results in mutant receptors that can be activated by ligands possessing hydrogen bond-accepting groups 
in place of the alkylamine side chain. Similar findings of complementarity between mutant transporters and "mutant" ligands would increase the implications that direct contacts between ligands and transporters were being evaluated through sitedirected mutagenesis. In the present study, we found that the D98E mutant compensates for disruptions in potency induced by alterations in substrate structure. Thus, gramine, bearing a methylamine side chain, was significantly more potent both as an inhibitor of 5HT uptake and at activating substrate-induced currents at the mutant D98E as compared with wild-type rSERT. Although the effect was not as dramatic as that seen with gramine, the shorter-chained analog of dopamine, DHBA, showed a similar preference for D98E, suggesting that catecholamines may be coordinated similarly to indoleamines, at least by SERTs. Interestingly, Buck and Amara (1994) also have implicated TMD I in substrate recognition for DATs through chimera studies. Antagonist ([ $\left.\left.{ }^{125} \mathrm{I}\right] \mathrm{RTI}-55\right)$ binding studies revealed a loss of affinity for 5 HT at D98E, whereas uptake studies revealed no change in the 5 HT $K_{\mathrm{m}}$ value. The determination of the transport $K_{\mathrm{m}}$ includes steps distal to binding, including translocation and release of substrates, and these additional steps may offset mutationinduced effects on 5HT binding. Additionally, the conditions of transport versus binding assays (e.g., $37^{\circ}$ vs $4^{\circ} \mathrm{C}$ ) may allow movements of either the acidic side chain on the transporter or the alkylamine chain of the substrate to accommodate 5HT. Gramine and DHBA, however, may already be in an extended conformation and require the lengthening of the acidic side chain at D98 to recover the potency seen for the ethylamines DMT and 5HT. Because the D98E mutant could promote favorable interactions between gramine with yet another residue, studies evaluating charge-charge interactions in support of this interaction are warranted.

Because D98 influences 5HT transport, we also determined whether this residue represents a critical contact site for transporter antagonists. Evidence such as protection against alkylating agents argues that competitive antagonists such as imipramine and cocaine possess mutually exclusive, overlapping binding sites with 5HT on SERT (Graham et al., 1989). However, comparisons of radioligand dissociation rates from native SERTs suggest heterogeneity in the binding of SERT antagonists and propose distinct ligand-specific contact sites (Plenge et al., 1987, 1991). For the D98E mutant, we observed a loss of affinity for cocaine as well as for the cocaine analog RTI-55, the tricyclic imipramine, and the SSRI citalopram. These effects, however, were not shared by all antagonists (e.g., mazindol, paroxetine), consistent with the existence of unique determinants of antagonist recognition. We recently linked Y95 in rSERT, located one helical turn away from D98 in TMD I, with species-specific recognition of some but not all SERT antagonists (Barker et al., 1998). In the context of our present studies, these findings support a model by which competitive antagonists can physically obstruct substrate binding sites in addition to conformational alterations arising from ligand binding (Ferrer and Javitch, 1998). Recently, Chen and coworkers (1997b), using SCAM techniques, identified both I172 and Y176 of TMD III as potential shared sites for the recognition of both 5HT and cocaine, supporting a model whereby TMDs III and I lie close together in the folded configuration of the membraneembedded transporter.

Not only does D98 appear to dictate ligand recognition, but the D98E mutation also compromises the SERT permeation pathway for nonstoichiometric ion flow (Mager et al., 1994; Lin et al., 1996). No detectable 5HT-induced current was observed for the
D98E mutant at pH 7.6. However, the D98E mutant was clearly expressed because (1) transport activity was present, (2) leak currents were intact, and (3) a shift of external $\mathrm{pH}$ to $\mathrm{pH} 5.0$ revealed substrate-gated currents. The loss of detectable 5HTactivated current in the D98E mutant expressing oocytes at $\mathrm{pH}$ 7.6 could be attributed to either a mutation-induced disruption of gating mechanisms or an alteration in permeant species or both. Because 5HT and other substrates can gate ion flow at $\mathrm{pH} 5.0$ and this activity still requires extracellular $\mathrm{Na}^{+}$, gating of ion flow per se appears to be intact. Single-channel analysis of SERTconducting states has suggested that $\mathrm{Na}^{+}$is a major currentcarrying species for both 5HT-activated and the substrateindependent leak currents (Lin et al., 1996), although recent studies suggest that $\mathrm{H}^{+}$may have significant permeability through these pathways (Cao et al., 1997; Sonders et al., 1997). Although the $\mathrm{Na}^{+}$and $\mathrm{Cl}^{-} K_{\mathrm{m}}$ values were elevated and can account for a loss of ion-coupled uptake capacity, this reduction in transport would not account for the D98E-induced disruption on 5HT-gated currents at neutral $\mathrm{pH}$ because 5HT carries a very small fraction of the total current (Mager et al., 1994; Galli et al., 1997). Because $5 \mathrm{HT}$ is essentially fully protonated at neutral $\mathrm{pH}$, the shift to acidic $\mathrm{pH}$, as argued previously by $\mathrm{Cao}$ and coworkers (1997), must reveal currents not by titrating 5HT but by either (1) titrating a functional group on SERT to permit cation flow disturbed by D98E or (2) increasing the driving force for $\mathrm{H}^{+}$flow across a permeation pathway unaffected by the D98E mutation. Analysis of the $\mathrm{pH}$ sensitivity of the reversal potential for the leak pathways of rSERT and D98E confirms that substrateindependent ion flow at acidic $\mathrm{pH}$ is essentially intact in D98E. However, although the 5HT-gated current of wild-type rSERT contains other charge carriers besides $\mathrm{H}^{+}$(and probably $\mathrm{Na}^{+}$), the D98E 5HT-gated current is essentially proton selective. This suggests that the mutation has impacted 5HT-gated ionic selectivity rather than gating per se such that $\mathrm{Na}^{+}$is no longer the major current-carrying species. We attempted to confirm a loss of $\mathrm{Na}^{+}$influx by D98E via [ $\left.{ }^{22} \mathrm{Na}\right]$ cotransport studies but found the expression levels of SERTs inadequate to achieve this measurement.

Because the D98E mutant affects the ion coupling of 5HT transport and eliminates a component of the substrate-activated conducting current, both of which involve $\mathrm{Na}^{+}$, ion selectivity in SERT channels may be determined by domains and residues that also participate in coupling $5 \mathrm{HT}$ permeation to ion gradients. The simplest model would involve substrate and ion flow, including $\mathrm{H}^{+}$, as routed through a common pathway whereby the D98E mutant retains the ability to pass $5 \mathrm{HT}$ and $\mathrm{H}^{+}$but no other ions. As discussed by Cao and coworkers (1997), the movement of protons through SERTs may involve conduction in a "waterwire" mechanism that $\mathrm{Na}^{+}$and other cations have no access to, whereas $\mathrm{Na}^{+}$conduction may require distinct structural elements that impact selectivity and conduction. Recent studies of Drosophila SERT currents (C. Petersen and L. DeFelice, unpublished observations) reveal anomalous mole fraction effects between $\mathrm{Na}^{+}$and $\mathrm{Li}^{+}$in the leak pathway that are abolished by 5HT, suggesting that the substrate itself may modify cation interactions in a common permeation pathway. Interestingly, GAT1 GABA transporters lack transmitter-gated nonstoichiometric ion flow (Mager et al., 1996), and the Gly at the position homologous to D98 in GAT1 may contribute to this biophysical distinction with biogenic amine transporters. We cannot rule out that two pathways for nonstoichiometric ion flow could be gated by $5 \mathrm{HT}$, one involved with proton permeation and a second, affected by the 
mutation, carrying other ions (and perhaps also 5HT) that comprise the bulk of the nonstoichiometric ion flow at neutral $\mathrm{pH}$. Besides a lack of positive data to support the latter model, 5HT appears to block rather than gate the leak pathway (when tested in the absence of $\mathrm{Na}^{+}$). In addition, direct single-channel recordings of substrate-independent and substrate-activated channels by Lin and coworkers (1996) indicate a similar conductance for the leak and 5HT-gated permeation pathways. Whichever model is correct, D98, and by extension TMD I, clearly constrains multiple facets of SERT function including $5 \mathrm{HT}, \mathrm{Na}^{+}, \mathrm{Cl}^{-}$, and antagonist recognition as well as ion permeation, effects that must be accommodated by models linking transporter structure to function. Given the conservation of the TMD I Asp in biogenic amine transporters, we suspect that our findings generalize to NETs and DATs.

\section{REFERENCES}

Akabas MH, Stauffer DA, Xu M, Karlin A (1992) Acetylcholine receptor channel structure probed in cysteine-substitution mutants. Science 258:307-310.

Barker EL, Blakely RD (1995) Norepinephrine and serotonin transporters: molecular targets for antidepressant drugs. In: Psychopharmacology: the fourth generation of progress (Bloom F, Kupfer D, eds) pp 321-333. New York: Raven.

Barker EL, Blakely RD (1996) Identification of a single amino acid, phenylalanine 586, that is responsible for high-affinity interactions of tricyclic antidepressants with the human serotonin transporter. Mol Pharmacol 50:957-965.

Barker EL, Kimmel HL, Blakely RD (1994) Chimeric human and rat serotonin transporters reveal domains involved in recognition of transporter ligands. Mol Pharmacol 46:799-807.

Barker EL, Perlman MA, Adkins EM, Houlihan WJ, Pristupa ZB, Niznik HB, Blakely RD (1998) High affinity recognition of serotonin transporter antagonists defined by species-scanning mutagenesis: an aromatic residue in transmembrane domain I dictates species-selective recognition of citalopram and mazindol. J Biol Chem 273:19459-19468.

Bennett ER, Kanner BI (1997) The membrane topology of GAT-1, a $\left(\mathrm{Na}^{+}\right.$and $\left.\mathrm{Cl}^{-}\right)$-coupled gamma-aminobutyric acid transporter from rat brain. J Biol Chem 272:1203-1210.

Blakely RD, Berson HE, Fremeau Jr RT, Caron MG, Peek MM, Prince HK, Bradley CC (1991a) Cloning and expression of a functional serotonin transporter from rat brain. Nature 354:66-70.

Blakely RD, Clark JA, Rudnick G, Amara SG (1991b) Vaccinia-T7 RNA polymerase expression system: evaluation for the expression cloning of plasma membrane transporters. Anal Biochem 194:302-308.

Boja JW, Mitchell WM, Patel A, Kopajtic TA, Carroll FI, Lewin AH, Abraham P, Kuhar MJ (1992) High-affinity binding of RTI-55 to dopamine and serotonin transporters in rat brain. Synapse 12:27-36.

Buck KJ, Amara SG (1994) Chimeric dopamine-norepinephrine transporters delineate structural domains influencing selectivity for catecholamines and 1-methyl-4-phenylpyridinium. Proc Natl Acad Sci USA 91:12584-12588.

Cao YW, Mager S, Lester HA (1997) $\mathrm{H}^{+}$permeation and $\mathrm{pH}$ regulation at a mammalian serotonin transporter. J Neurosci.17:2257-2266.

Cao YW, Li MY, Mager S, Lester HA (1998) Amino acid residues that control $\mathrm{pH}$ modulation of transport-associated current in mammalian serotonin transporters. J Neurosci 18:7739-7749.

Chen JG, Liu-Chen S, Rudnick G (1997a) External cysteine residues in the serotonin transporter. Biochemistry 36:1479-1486.

Chen JG, Sachpatzidis A, Rudnick G (1997b) The third transmembrane domain of the serotonin transporter contains residues associated with substrate and cocaine binding. J Biol Chem 272:28321-28327.

Chen JG, Liu-Chen S, Rudnick G (1998) Determination of external loop topology in the serotonin transporter by site-directed chemical labeling. J Biol Chem 273:12675-12681.

Cheng Y, Prusoff WH (1973) Relationship between the inhibition constant and the concentration of inhibitor that causes 50 percent inhibition of an enzymatic reaction. Biochem Pharmacol 22:3099-3108.

Clark JA (1997) Analysis of the transmembrane topology and membrane assembly of the GAT-1 gamma-aminobutyric acid transporter. J Biol Chem 272:14695-14704.

Ferrer JV, Javitch JA (1998) Cocaine alters the accessibility of endoge- nous cysteines in putative extracellular and intracellular loops of the human dopamine transporter. Proc Natl Acad Sci USA 95:9238-9243.

Fuerst TR, Niles E, Studier FW, Moss B (1986) Eukaryotic transient expression system based on recombinant vaccinia virus that synthesizes bacteriophage T7 RNA polymerase. Proc Natl Acad Sci USA 83:8122-8126.

Galli A, DeFelice LJ, Duke BJ, Moore KR, Blakely RD (1995) Sodiumdependent norepinephrine-induced currents in norepinephrinetransporter-transfected HEK-293 cells blocked by cocaine and antidepressants. J Exp Biol 198:2197-2212.

Galli A, Blakely RD, DeFelice LJ (1996) Norepinephrine transporters have channel modes of conduction. Proc Natl Acad Sci USA 93: 8671-8676.

Galli A, Petersen CI, deBlaquiere M, Blakely RD, DeFelice LJ (1997) Drosophila serotonin transporters have voltage-dependent uptake coupled to a serotonin-gated ion channel. J Neurosci 17:3401-3411.

Graham D, Esnaud H, Habert E, Langer SZ (1989) A common binding site for tricyclic and nontricyclic 5-hydroxytryptamine uptake inhibitors at the substrate recognition site of the neuronal sodium-dependent 5-hydroxytryptamine transporter. Biochem Pharmacol 38:3819-3826.

Gu H, Wall SC, Rudnick G (1994) Stable expression of biogenic amine transporters reveals differences in inhibitor sensitivity, kinetics, and ion dependence. J Biol Chem 269:7124-7130.

Humphreys CJ, Wall SC, Rudnick G (1994) Ligand binding to the serotonin transporter: equilibria, kinetics, and ion dependence. Biochemistry 33:9118-9125.

Kitayama S, Shimada S, Xu H, Markham L, Donovan DM, Uhl GR (1992) Dopamine transporter site-directed mutations differentially alter substrate transport and cocaine binding. Proc Natl Acad Sci USA 89:7782-7785.

Kunkel TA, Roberts JD, Zakour RA (1987) Rapid and efficient sitespecific mutagenesis without phenotypic selection. Methods Enzymol 154:367-382.

Lester HA, Cao YW, Mager S (1996) Listening to neurotransmitter transporters. Neuron 17:807-810.

Lin F, Lester HA, Mager S (1996) Single-channel currents produced by the serotonin transporter and analysis of a mutation affecting ion permeation. Biophys J 71:3126-3135.

Mager S, Min C, Henry DJ, Chavkin C, Hoffman BJ, Davidson N, Lester HA (1994) Conducting states of a mammalian serotonin transporter. Neuron 12:845-859.

Mager S, Kleinberger-Doron N, Keshet GI, Davidson N, Kanner BI, Lester HA (1996) Ion binding and permeation at the GABA transporter GAT1. J Neurosci 16:5405-5414.

Melikian HE, McDonald JK, Gu H, Rudnick G, Moore KR, Blakely RD (1994) Human norepinephrine transporter. Biosynthetic studies using a site-directed polyclonal antibody. J Biol Chem 269:12290-12297.

Melikian HE, Ramamoorthy S, Tate CG, Blakely RD (1996) Inability to $\mathrm{N}$-glycosylate the human norepinephrine transporter reduces protein stability, surface trafficking, and transport activity but not ligand recognition. Mol Pharmacol 50:266-276.

Nelson N (1998) The family of $\mathrm{Na}^{+} / \mathrm{Cl}^{-}$neurotransmitter transporters. J Neurochem 71:1785-1803.

Pacholczyk T, Blakely RD, Amara SG (1991) Expression cloning of a cocaine- and antidepressant-sensitive human noradrenaline transporter. Nature 350:350-354.

Plenge P, Mellerup ET, Honore T, Honore PL (1987) The activity of 25 paroxetine/femoxetine structure variants in various reactions, assumed to be important for the effect of antidepressants. J Pharm Pharmacol 39:877-882.

Plenge P, Mellerup ET, Laursen H (1991) Affinity modulation of $\left[{ }^{3} \mathrm{H}\right] \mathrm{i}-$ mipramine, $\left[{ }^{3} \mathrm{H}\right]$ paroxetine and $\left[{ }^{3} \mathrm{H}\right]$ citalopram binding to the $5 \mathrm{HT}$ transporter from brain and platelets. Eur J Pharmacol 206:243-250.

Qian Y, Melikian HE, Rye DB, Levey AI, Blakely RD (1995) Identification and characterization of antidepressant-sensitive serotonin transporter proteins. J Neurosci 15:1261-1274.

Qian Y, Galli A, Ramamoorthy S, Risso S, DeFelice LJ, Blakely RD (1997) Protein kinase C activation regulates human serotonin transporters in HEK-293 cells via altered cell surface expression. J Neurosci $17: 45-57$.

Ramamoorthy S, Melikian HE, Qian Y, Blakely RD (1998) Biosynthesis, N-glycosylation, and surface trafficking of biogenic amine transporter proteins. In: Methods in enzymology: neurotransmitter transporters (Amara SG, ed), pp 347-370. San Diego: Academic. 
Rudnick G (1998a) Bioenergetics of neurotransmitter transport. J Bioenerg Biomembr 30:173-185.

Rudnick G (1998b) Ion-coupled neurotransmitter transport: thermodynamic vs. kinetic determinations of stoichiometry. In: Methods in enzymology: neurotransmitter transporters (Amara SG, ed), pp 233247. San Diego: Academic.

Rudnick G, Clark J (1993) From synapse to vesicle: the reuptake and storage of biogenic amine neurotransmitters. Biochim Biophys Acta 1144:249-263.

Rudnick G, Wall SC (1992) The molecular mechanism of "ecstasy": serotonin transporters are targets for MDMA-induced serotonin release. Proc Natl Acad Sci USA 89:1817-1821.

Rudnick G, Talvenheimo J, Fishkes H, Nelson PJ (1983) Sodium ion requirements for serotonin transport and imipramine binding. Psychopharmacol Bull 19:545-549.

Sanger F, Nicklen S, Coulson AR (1977) DNA sequencing with chainterminating inhibitors. Proc Natl Acad Sci USA 74:5463-5467.

Sonders MS, Zhu SJ, Zahniser NR, Kavanaugh MP, Amara SG (1997) Multiple ionic conductances of the human dopamine transporter: the actions of dopamine and psychostimulants. J Neurosci 17:960-974.
Stauffer DA, Karlin A (1994) Electrostatic potential of the acetylcholine binding sites in the nicotinic receptor probed by reactions of bindingsite cysteines with charged methanethiosulfonates. Biochemistry 33:6840-6849.

Strader CD, Sigal IS, Dixon RA (1989) Structural basis of betaadrenergic receptor function. FASEB J 3:1825-1832.

Strader CD, Gaffney T, Sugg EE, Candelore MR, Keys R, Patchett AA, Dixon RA (1991) Allele-specific activation of genetically engineered receptors. J Biol Chem 266:5-8.

Tatsumi M, Groshan K, Blakely RD, Richelson E (1997) Pharmacological profile of antidepressants and related compounds at human monoamine transporters. Eur J Pharmacol 340:249-258.

Wall SC, Innis RB, Rudnick G (1993) Binding of the cocaine analog 2 beta-carbomethoxy-3 beta-(4-[ $\left.{ }^{125} \mathrm{I}\right]$ iodophenyl)tropane to serotonin and dopamine transporters: different ionic requirements for substrate and 2 beta-carbomethoxy-3 beta-(4-[ $\left.{ }^{125} \mathrm{I}\right]$ iodophenyl)tropane binding. Mol Pharmacol 43:264-270.

White FJ (1998) Drug addiction: cocaine and the serotonin saga. Nature 393:118-119. 